\title{
Ureide metabolism in plant-associated bacteria: purine plant-bacteria interactive scenarios under nitrogen deficiency
}

\author{
María Luisa Izaguirre-Mayoral • George Lazarovits • \\ Bikash Baral
}

Received: 13 December 2017 / Accepted: 3 May 2018/Published online: 25 May 2018

(C) Springer International Publishing AG, part of Springer Nature 2018

\begin{abstract}
Background The erratic alterations in climate being experienced in agriculture, such as extended periods of drought or heavy rainfalls, are bringing increasing concerns about nitrogen $(\mathrm{N})$ management. Even in highinput farming systems, unpredictable weather patterns can cause $\mathrm{N}$ deficiencies and result in nutrient losses that contribute to major pollution issues in groundwater, lakes, and even the oceans. Our present understanding of the beneficial interactions between N-deficientchallenged plants and plant-associated bacteria (PAB), mainly of the phyla Actinobacteria, Bacteroidetes, Firmicutes, and Proteobacteria, is largely based on
\end{abstract}

Responsible Editor: Elizabeth M Baggs.

Electronic supplementary material The online version of this article (https://doi.org/10.1007/s11104-018-3674-x) contains supplementary material, which is available to authorized users.

M. L. Izaguirre-Mayoral

Academia de Ciencias de America Latina, Palacio de las Academias, Distrito Federal, Apartado Postal 1121-A, Caracas, Venezuela

\section{G. Lazarovits}

A\&L Biologicals, Agroecological Research Services Centre, London, ON N5V 3P51, Canada

B. Baral $(\bowtie)$

Department of Biochemistry, University of Turku, 20500 Turku, Finland

e-mail: bikash.baral@utu.fi studies performed at the level of whole-plant fitness and impacts of crop yields via the abilities of bacteria to synthesize indole acetic acid and/or produce the enzyme 1-aminocyclopropane-1-carboxylate deaminase which reduces endogenous ethylene levels. Much less is known about the complex interaction that occur from the PAB's abilities to produce $\mathrm{N}$ ureide (allantoin and allantoate) and how these purine intermediaries function as an $\mathrm{N}$ source and prime stress signals for the growth of both partners.

Methods This review examines the noteworthy progress made on understanding the bacterial ureide pathway with the aim to elaborate possible scenarios to unravel the complex nature of PAB-plant interactions at the purine level. Tables with updated information on PAB growth-promoting activities, $\mathrm{N}$ metabolism, and abilities to hydrolyze purine intermediates as well as allantoin for colony growth are included.

Results As in plants, the metabolism of ureides in PAB covers the pathways from the deamination of the nucleobase guanine up to its conversion into glyoxylate, $\mathrm{NH}_{4}{ }^{+}$, and/or $\mathrm{NH}_{3}$ to recycle $\mathrm{C}$ and N. More important, in $\mathrm{PAB}$, the full set of riboswitch-modulated genes encoding the enzymes involved in the synthesis and catabolism of ureides, as well as purine transporters, is expressed primarily under stressful conditions leading to $\mathrm{N}$ deficiency. Thus, PAB might act as a stress-induced source of purines for the plant $\mathrm{N}$ metabolism, or could become scavengers of the plant-synthesized purines for colony replication. Consumption of purine intermediaries or ureides by PAB may hinder the symbiotic 
efficiency of rhizobia-nodulated $\mathrm{N}_{2}$-fixing legumes. The impact of soil xanthine, hypoxanthine, and allantoin pools on the plants or PAB ureide synthesis is also discussed.

Conclusions Given widespread concerns for crop losses due to the drastically changing climate and prevailing agricultural practices, the understanding of the interactive signaling for the purine metabolisms between $\mathrm{PAB}$ and plants takes on a major importance, as it may support management decisions necessary to maintain PAB biodiversity and the agricultural services provided by PAB to crops.

Keywords ACC deaminase - Allantoin - Growthpromoting bacteria $\cdot$ Indole acetic acid $\cdot \mathrm{N}_{2}$-fixers . Xanthine $\cdot$ Hypoxanthine

\section{Introduction}

Nitrogen $(\mathrm{N})$ is a crucial factor limiting crop productivity in many terrestrial ecosystems and its availability in soils largely depends on the rates of the microorganisms driven mineralization of organically bound $\mathrm{N}$ into plantavailable inorganic forms of ammonium $\left(\mathrm{NH}_{4}{ }^{+}\right)$and nitrate $\left(\mathrm{NO}_{3}{ }^{-}\right)$(Cronan 2018). However, there is an increasing concern about the more frequent occurrence of $\mathrm{N}$ deficiency in agricultural soils, even in farming systems with large inputs of $\mathrm{N}$ fertilizer, as a result of more frequent and severe drought spells brought about by climate change (Wang et al. 2018) that negatively impacts soil microbial biomass (Nguyen et al. 2018). Even transitory reductions in the amount of rainfall decrease the size of soil microbial populations as well as the plant microbiome recruitment traits (Naylor and Coleman-Derr 2018; Ren et al. 2018). Evidences to support the negative impact of drought on the size of soil microbial populations involved in $\mathrm{N}$ cycling are $(i)$ the reduced activity of microbial urease enzyme involved in the hydrolysis of urea to $\mathrm{CO}_{2}$ and $\mathrm{NH}_{3}$ in dry soils (Xue et al. 2017) and (ii) the negative correlation between aridity and the gross soil $\mathrm{N}$ mineralization $(p<0.01)$ or $\mathrm{NH}_{4}{ }^{+}$immobilization $(p<0.05)$ (Kou et al. 2018). This situation is also complicated by the accumulation of high salt concentrations in drying soils that negatively impact soil microbial activity limiting soil $\mathrm{N}$ mineralization (Numan et al. 2018). Seasonal drought and salinity are known to be accompanied by soil $\mathrm{N}$ deficiency and this also negatively impacts plant growth, physiology, and N-ureide metabolism (Baral and Izaguirre-Mayoral 2017). Moreover, carbon (C) starvation of belowground organs and soil microorganisms (brought about by the reductions in photosynthesis created under drought and salinity) enhances competition for the limited soil $\mathrm{N}$ between soil microbiome and active roots (Simon et al. 2017).

To survive under stressful conditions, plants and plant-associated bacteria (PAB) developed adaptativestrategic associations via inter- and intraspecies signaling as well as the modulation of plant immunity process to allow PAB to colonize the surface of roots (rhizospheric) and leaves (phyllospheric) and/or different plant tissues (endophytic) (Chagas et al. 2018; Fitzpatrick et al. 2018). In general, soils are largely the main source of bacterial diversity, with the greatest plethora of potentially effective PAB being concentrated in the bulk soil (Castellano-Hinojosa et al. 2016; Rauwane et al. 2017). The largest, but less diverse microbial populations occur in the rhizosphere. Selection here is linked to utilization of plant nutrient sources, but such organisms are also under the influence of faster dehydration associated to salinity brought about by the increased plant transpiration rates required to sustain low stomatal resistance during drought spells (Ibekwe et al. 2017). This can result in the survival of only abiotic stress-tolerant bacteria, as constrained also by the selection of plant genetic traits (Wu et al. 2018). However, to maintain metabolic functionality under these stressful $\mathrm{N}$-deficient conditions, the stresstolerant bacteria should enhance their rates of soil $\mathrm{N}$ uptake to mineralize $\mathrm{C}$ causing a severe $\mathrm{N}$ mining of the plant-available soil N (Meyer et al. 2017; Simon et al. 2017). Overall, interactions between prevailing environmental conditions and various operons within the bacterial N-regulation system ( $n t r)$, responsible for the degradation and/or uptake of diverse $\mathrm{N}$ sources, seem to be the key factors to modulate $\mathrm{N}$ utilization and production of $\mathrm{N}$ scavenging enzymes in bacteria (Ghosh et al. 2017). The expression of at least nine genes associated to the $\mathrm{N}$ metabolism allows Brucellas abortus to survive under culture conditions of nutrient starvation (Zai et al. 2017).

PAB species belonging to the phyla Actinobacteria (Supplemental Table S1), Bacteroidetes (Supplementary Table S2), and Firmicutes (Supplementary Table S3), as well as subphyla $\alpha, \beta$, and $\gamma$-Proteobacteria (Supplementary Tables S4, S5, S6) are commonly found in all agricultural soils (de Matos et al. 2017). The 
phylum Actinobacteria plays an important role as soil organic matter decomposers; whereas, the phyla Firmicutes and Proteobacteria, generally categorized as copiotrophs - fast growing organisms - prefer soil Crich environments as energy source to sustain high growth rates (Rebollar et al. 2017). Plants also host a consortium of a taxonomically diverse group of PAB, all positively strengthening the performance of abiotically challenged plants (Numan et al. 2018; Shameer and Prasad 2018), mostly of the genera Acinetobacter, Alcaligenes, Arthrobacter, Azospirillium, Azotobacter, Bacillus, Beijerinckia, Enterobacter, Erwinia, Flavobacterium, and Serratia. Members of the Curtobacterium genus were described mainly in the phyllosphere and seldom are associated with roots or as endophytic symbionts (Chase et al. 2016). A typical example of PAB was reported for plants of the Poaceae family (maize, wheat, pearl millet, sorghum, and rice) of Gujarat region in India revealing the average presence of 37\% Actinobacteria (Aeromicrobium sp., Arthobacter sp., Microbacterium sp., Staphylococcus sp.), 23\% $\beta$ Proteobacteria (Achromobacter sp. and Ralstonia sp.), $20 \% \alpha$-Proteobacteria (Rhizobium sp., Brevundimonas sp., and Methylobacterium sp.), $10 \% \gamma$-Proteobacteria (Acinetobacter sp., Pseudomonas sp., and Pantoea sp.), and 10\% Firmicutes (Streptomyces sp. and Bacillus sp.) (Patel and Archana 2017). For agricultural purposes, the positive synergism shown by PAB consortia on stresschallenged plants, when compared with single bacteria inoculations, may be most promising for increasing crop fitness (Chinnaswamy et al. 2018; Hajnal-Jafari et al. 2018). Moreover, the consortia of bacterial endophytes in seeds are of particular importance because they facilitate seed germination in stress-constrained soils and are the source of inoculum to successive plant generations via vertical transmission (see Plant and Soil special issues 1-2 Volume 422, January 2018). Noteworthy is the influence of belowground PAB on floral traits that mediate interactions between plants and pollinators (Rolli et al. 2015), and the impact of the size of soil particles on the bacterial diversity found in soils (Hemkemeyer et al. 2018). The mechanisms for the entry of PAB to plant cells and their translocation to different plant organs were recently discussed by Chagas et al. (2018) and Rodríguez et al. (2018).

The magnitude of the positive effects exerted by PAB on drought- and salinity-challenged plants seems to be enhanced by the bacterial ability to cleave plantsynthesized 1-aminocyclopropane-1-carboxylate
(ACC), the immediate biosynthetic precursor of ethylene, into $\mathrm{NH}_{3}$ and $\alpha$-ketobutyrate via the enzyme ACC deaminase (ACCD), as a way to use this additional $\mathrm{N}$ source (Nascimento et al. 2018). Bacterial ACCD is a sulfhydryl multimeric enzyme with a monomeric subunit molecular mass between 35 and $42 \mathrm{kDa}$ and pyridoxal 5-phosphate as co-factor encoded by acd $S$ genes (Soni et al. 2018). In Sinorhizobium meliloti, acdS has a polyphyletic origin obtained through horizontal gene transfer, its expression is induced by root exudates of legumes and non-leguminous plants, and it is negatively regulated by a putative leucine-responsive regulator (LrpL) located upstream to $a c d S$ sequence $(a c d R)$ (Checcucci et al. 2017). High rates of ACCD production under drought and salinity conditions were reported in Bacillus simplex (Soleimani et al. 2017), and ACCD activity linked to plant growth-promoting traits was described for the first time in the genus Citrobacter and Empedobacter isolated from wheat rhizosphere (Gontia-Mishra et al. 2017). In the case of droughtchallenged rhizobia-nodulated legumes, the presence of PAB expressing ACCD activity counteracts the negative effects of high ethylene levels on root nodulation (Nascimento et al. 2018). On the other hand, synthesis of indole acetic acid (IAA) in PAB is enhanced under conditions of limited N (Otanga et al. 2018) and plays a pivotal role on PAB promoting plant growth. The negative effects of drought and salinity seem to be further counteracted in plants co-inoculated by PAB expressing ACCD activity and IAA production, in spite of the IAA stimulating the activity of ACC synthase in plants (Vargas et al. 2017). Bacteria expressing ACCD activity and/or producing IAA are listed in Supplementary Tables S1 to S6.

In parallel, $\mathrm{N}$-deficient crops may also benefit from the $\mathrm{N}_{2}$-fixing abilities in a large number of PAB belonging to the agriculturally important $\alpha$-Proteobacteria (order Rhizobiales) in symbiosis mainly with legumes and $\beta$-Proteobacteria (order Burkholderiales) as well as in the phylum Firmicutes (Order Bacillales) (Supplementary Tables S1-S6). In nodulated $\mathrm{N}_{2}$-fixing legumes, the effectiveness of the symbiosis with rhizobia, nutrient uptake, and seed yield are enhanced by the plant coinoculation with non- $\mathrm{N}_{2}$-fixing PAB such as Streptomyces griseoflavus (Htwe et al. 2018). The use of the nifH gene encoding the nitrogenase reductase subunit, the most widely established molecular marker for the study of $\mathrm{N}_{2}$-fixing prokaryotes, as indicator of the $\mathrm{N}_{2}$-fixing properties of PAB was recently questioned 
(Emmyrafedziawati and Stella 2018). In the case of nodulated $\mathrm{N}_{2}$-fixing legumes, the abundance of $\mathrm{C}$ and $\mathrm{N}$ in the root exudates triggers the profusion of rhizospheric PAB (Gao et al. 2017). Moreover, the $\mathrm{N}_{2^{-}}$ fixing nodules in legumes are $\mathrm{C}, \mathrm{N}$, and phosphorus $(\mathrm{P})$ enriched and thus are readily colonized by diverse groups of PAB in intimate co-existence with the nodulating rhizobia (Table 1). As indicated by Xiao et al. (2017), the taxonomic composition of nodule endophytes is primarily determined by plant species. Although, new evidences suggest the predominant influence of the soil type as major driver for the composition of the microbiome associated to root nodules (Leite et al. 2017). This suggestion is further supported by the direct effect of soil $\mathrm{N}$ on the percentage of nodule occupancy by non-rhizobial bacteria ranking from 56 to $87 \%$ in low $\mathrm{N}$ to less than $50 \%$ in high $\mathrm{N}$ grown Dalbergia odorifera (Lu et al. 2017).

An exhaustive review of the published literature on plant-PAB interactions points out growth and crop yield responses under drought or salinity conditions as the main focus of experimental investigations (i.e., Batista et al. (2018); Etesami (2018); Bounaffaa et al. (2018)). Much less is known about the $\mathrm{N}$ pathways and possible $\mathrm{N}$ signalings mediating interactions between the plant and its PAB. As reviewed by Baral and IzaguirreMayoral (2017), ureides (allantoin and allantoate) enhance the tolerance of legumes and non-legumes to drought and salinity stress, mainly due to the allantoin function as $\mathrm{N}$ source and as prime signal for the induction of plant defense mechanisms. Nevertheless, ureides are not an exclusive $\mathrm{N}$ product of the purine metabolism in $\mathrm{N}_{2}$-fixing plants since many bacteria harbor the full set of genes encoding for the activity of enzymes and purine transporters involved in the synthesis and catabolism of ureides, triggered by stressful conditions like $\mathrm{N}$ deficiency (Petridis et al. 2015; Ma et al. 2016). Therefore, we propose that a key role is played by the production of bacterial $\mathrm{N}$ ureides. In most bacteria, the purine metabolism covers steps from the deamination of the nucleobase guanine up to its final conversion of the $\mathrm{N}$ intermediate into glyoxylate, $\mathrm{NH}_{4}{ }^{+}$, and/or $\mathrm{NH}_{3}$, allowing cells to recover $\mathrm{C}$ and $\mathrm{N}$. Curiously, while purine metabolism is acknowledged as an important survival trait for microbes grown in stressed environments, its explicit consequences for plants are not addressed in most studies. However, identifying the roles of bacterially produced ureides is complicated by the fact that plants simultaneously produce precisely the same purine molecules. Thus, this review will present noteworthy progress on understanding the bacterial ureide synthesis and catabolism with the final aim to elaborate possible scenarios to unravel the complex nature of bacterial-plant interactions, at the purine level. Due to the complexity of the microbiome associated with plants, the analyses of the purine metabolism will concentrate mainly on bacteria, with emphasis on the bacterial species or isolates fully identified with $98-100 \%$ similarity with reference strains. The names of the bacterial species are mentioned as in the cited references, although we are aware of the recent re-classification of a number of Pseudomonas and Azospirillum strains into different genospecies (Tran et al. 2017; Maroniche et al. 2017) as well as of the split of the genera Burkholderia and Paraburkholderia (Martínez-Hidalgo and Hirsch 2017).

\section{Bacterial ureide synthesis}

Description of the four metabolic steps for the synthesis of ureides

In a similar way to plants, ureide synthesis in bacteria takes place in four consecutive enzymatic steps (see Fig. 3 in Baral et al. (2016)). The first step, described in Bacillus subtilis, is the deamination of guanine to hypoxanthine catalyzed by the enzyme guanine deaminase (Rivas et al. 2018). For this step, guanine riboswitches (Gong et al. 2018) regulate the transcription of xpt-pbuX operon in B. subtilis, Staphylococcus aureus and in the vast majorities of Firmicutes (Kofoed et al. 2016; Laney and Morse 2017; Kirchner and Schneider 2017). The second step is the conversion of hypoxanthine into xanthine and then to uric acid by the enzyme xanthine oxidoreductase (XOR) that occurs in two isoforms: the xanthine dehydrogenase $(\mathrm{XDH})$ and the xanthine oxidase (XO). The third step consists of three major enzymatic reactions: ( $i$ ) the oxidation of the uric acid to 5-hydroxyisourate (HIU) via a coenzymeindependent enzyme urate oxidase (UOX), also known as uricase, in a two stage - oxidation followed by hydration-in B. subtilis and B. fastidiosus (Wei et al. 2016); (ii) the conversion of HIU to 5-hydroxy-2-oxo4-ureido-2,5-dihydro-1H-imidazole-5-carboxylate (OHCU) catalyzed by the putative xanthine upregulated transthyretin-related proteins 5-hydroxyisourate hydrolase as in Escherichia coli (Urano et al. 2015); and, (iii) the stereoselective decarboxylation of $\mathrm{OHCU}$ to the 
Table 1 Examples of endophytes, besides well-known rhizobia, isolated from root nodules of legumes and actinorhizal plants

\begin{tabular}{|c|c|c|}
\hline Host & Nodule endophytes & References \\
\hline Abrus precatorius & Ensifer abri, Rhizobium tropici & (Bautista et al. 2017; Suneja et al. 2017) \\
\hline Acacia abyssinica & Mesorhizobium abyssinicae, M. shonense & (Peix et al. 2015) \\
\hline Acacia angustissima & Ensifer mexicanus & (Peix et al. 2015) \\
\hline Acacia salicina, Acacia stenophylla & $\begin{array}{l}\text { Achromobacter xylosoxidans, Acinetobacter } \\
\text { haemolyticus, Brevibacillus brevis, } \\
\text { Caulobacter vibrioides, Chitinophaga } \\
\text { sancti, Comamonas testosteroni, Devosia } \\
\text { neptuniae, Herbaspirillum frisingense, } \\
\text { Microbacterium trichothecenolyticum, } \\
\text { Mycobacterium frederiksbergense, } \\
\text { Paenibacillus agarexedens, P. amylolyticus, } \\
\text { P. glycanilyticus, P. pabuli, } \\
\text { Phyllobacterium trifolii, Stenotrophomonas } \\
\text { maltophilia, Variovorax paradoxus }\end{array}$ & (Hoque et al. 2011) \\
\hline Acacia melanoxylon & $\begin{array}{l}\text { Bradyrhizobium ganzhouense, } \\
\text { Mesorhizobium acaciae }\end{array}$ & (Suneja et al. 2017) \\
\hline Acacia senegal & Ensifer arboris, E. kostiensis & (Peix et al. 2015; Suneja et al. 2017) \\
\hline Aeschynomene indica & $\begin{array}{l}\text { Blastobacter capsulatus, Bradyrhizobium } \\
\text { oligotrophicum }\end{array}$ & $\begin{array}{l}\text { (Manju and Prabakaran 2016; Suneja et al. } \\
\text { 2017) }\end{array}$ \\
\hline Albizia kalkora & Mesorhizobium albiziae & (Suneja et al. 2017) \\
\hline Alhagi sparsifolia & Mesorhizobium alhagi, M. camelthorni & (Suneja et al. 2017) \\
\hline Alnus glutinos & $\begin{array}{l}\text { Micromonosporae cremea, } \text { M. coxensis, } \\
\text { M. lupini, M. matsumotoense, } \\
\text { M. olivasterospora, } \text { M. saelicesensis, } \\
\text { M. siamensis }\end{array}$ & (Trujillo et al. 2015) \\
\hline Alnus viridis & $\begin{array}{l}\text { Micromonosporae chokoriensis, } \text { M. coriariae, } \\
\text { M. lupini, M. matsumotoense, } \text { M. pisi, } \\
\text { M. rifamycinica, } \text { M. saelicesensis }\end{array}$ & (Trujillo et al. 2015) \\
\hline Amorpha fruticosa & Mesorhizobium amorphae & (Suneja et al. 2017) \\
\hline Alysicarpus nummularifolius & $\begin{array}{l}\text { Ensifer mexicanus, Rhizobium etli, } \\
\text { Stenotrophomonas maltrophilia }\end{array}$ & (Bautista et al. 2017) \\
\hline Amphicarpaea trisperm & Rhizobium yanglingense & (Peix et al. 2015) \\
\hline Anagyris latifolia & Mesorhizobium tamadayense & (Peix et al. 2015) \\
\hline Anthyllis vulneraria & $\begin{array}{l}\text { Aminobacter anthyllidis, Mesorhizobium } \\
\text { metallidurans, Rhodococcus strains }\end{array}$ & $\begin{array}{l}\text { (Martínez-Hidalgo and Hirsch 2017; Suneja } \\
\text { et al. 2017) }\end{array}$ \\
\hline Arachis hypogaea & $\begin{array}{l}\text { Bradyrhizobium arachidis, } \\
\text { B. guangdongense, B. guangxiense, } \\
\text { B. kavangense, B. manausense, } \\
\text { B. subterraneum, B. vignae, } \\
\text { B. yuanmingense, Inquillinus limosus, } \\
\text { Mesorhizobium plurifarium, Rhizobium } \\
\text { pakistanensis, R. larrymoorei }\end{array}$ & $\begin{array}{l}\text { (Hossain and Lundquist 2016; Bautista et al. } \\
\text { 2017; Suneja et al. 2017; Velázquez et al. } \\
\text { 2017a) }\end{array}$ \\
\hline Argyrolobium uniflorum & $\begin{array}{l}\text { Ensifer garamanticus, E. numidicus, } \\
\text { Phyllobacterium leguminum }\end{array}$ & (Mantelin et al. 2006; Peix et al. 2015) \\
\hline Astragalus adsurgens & Mesorhizobium septentrionale, M. gobiense & (Suneja et al. 2017) \\
\hline Astragalus algerianus & Phyllobacterium ifriqiyense, $P$. leguminum & (Mantelin et al. 2006) \\
\hline A. chrysopterus & Nocardioides astragali & (Xu et al. 2018) \\
\hline A. filicaulis & Mesorhizobium gobiense & (Peix et al. 2015) \\
\hline A. luteolus & Mesorhizobium sangaii & (Suneja et al. 2017) \\
\hline A. membranaceus & & (Yan et al. 2016) \\
\hline
\end{tabular}


Table 1 (continued)

\begin{tabular}{|c|c|c|}
\hline Host & Nodule endophytes & References \\
\hline & $\begin{array}{l}\text { Mesorhizobium septentrionale, } \\
\text { M. tianshanense, Pararhizobium herbae }\end{array}$ & \\
\hline A. mongholicus & $\begin{array}{l}\text { Mesorhizobium ciceri, M. septentrionale, } \\
\text { M. temperatum }\end{array}$ & (Yan et al. 2016) \\
\hline A. sinicus & Mesorhizobium huakuii, M. qingshengii & (Suneja et al. 2017) \\
\hline Biserrula pelecinus & $\begin{array}{l}\text { Mesorhizobium australicum, } \\
\text { M. opportunistum }\end{array}$ & (Suneja et al. 2017) \\
\hline Calliandra grandiflora & $\begin{array}{l}\text { Rhizobium calliandrae, } R \text {. jaguaris, } \\
\quad \text { R. mayense }\end{array}$ & (Suneja et al. 2017) \\
\hline Calopogonium mucunoides & $\begin{array}{l}\text { Bradyrhizobium elkanii, B. liaoningense, } \\
\quad \text { Enterobacter cloacae, Herbaspirillum putei }\end{array}$ & (Bautista et al. 2017) \\
\hline Caragana bicolour, C. erinace & Mesorhizobium shangrilense & (Suneja et al. 2017) \\
\hline Caragana grandiflora & Rhizobium calliandrae & (Suneja et al. 2017) \\
\hline Caragana intermedia & Neorhizobium alkalisoli, Rhizobium alkalisoli & (Suneja et al. 2017) \\
\hline Casuarina equisetifolia & Micromonosporae aurantiaca & (Trujillo et al. 2014) \\
\hline Centrolobium paraense & $\begin{array}{l}\text { Bradyrhizobium centrolobii, B. macuxiense, } \\
\text { B. neotropicale }\end{array}$ & (Zilli et al. 2014; Michel et al. 2017) \\
\hline Centrosema macrocarpum & Bradyrhizobium americanum & (Ramírez-Bahena et al. 2016) \\
\hline Centrosema molle & Bradyrhizobium centrosemae & (Ramírez-Bahena et al. 2016) \\
\hline Centrosema pubescens & Bradyrhizobium viridifuturi & (Suneja et al. 2017) \\
\hline Cicer arietinum & $\begin{array}{l}\text { Mesorhizobium muleiense, Paenibacillus } \\
\text { endophyticus, Serratia marcescens }\end{array}$ & $\begin{array}{l}\text { (Carro et al. 2013; Peix et al. 2015; Zaheer } \\
\text { et al. 2016) }\end{array}$ \\
\hline $\begin{array}{l}\text { Cicer arietinum, Cytisus scoparius, } \\
\text { Glycyrrhiza uralensis }\end{array}$ & Brevibactaerium spp., Ochrobactrum spp. & (Martínez-Hidalgo and Hirsch 2017) \\
\hline Chamaecytisus proliferus & Bradyrhizobium canariense & (Peix et al. 2015) \\
\hline Clitoria ternatea & $\begin{array}{l}\text { Achromobacter xylosoxidans, Bradyrhizobium } \\
\text { yuanmingense, Enterobacter cloacae, } \\
\text { E. hormaechei, E. turicensis, Rhizobium } \\
\text { rhizogenes, Sphingobacterium } \\
\text { thalpophilum, Pseudomonas alcaliphila, } \\
\text { P. geniculata, Stenotrophomonas } \\
\text { maltophilia }\end{array}$ & (Aeron et al. 2015; Bautista et al. 2017) \\
\hline Coriaria myrtifolia & $\begin{array}{l}\text { Micromonosporae coriarie, } M . \text { saelicesensis, } \\
\quad \text { M. peucetia }\end{array}$ & (Trujillo et al. 2014) \\
\hline Coronilla varia & Rhizobium yanglingense & (Peix et al. 2015) \\
\hline $\begin{array}{l}\text { Crotalaria glaucoides, C. perrottetii, } \\
\text { C. podocarpa }\end{array}$ & $\begin{array}{l}\text { Lotononis bainesii, Methylobacterium } \\
\quad \text { nodulans }\end{array}$ & (Jourand et al. 2004) \\
\hline Crotalaria pallida & Bradyrhizobium elkanii, B. liaoningense & (Bautista et al. 2017) \\
\hline Cytisus villosus & Bradyrhizobium cytisi, B. rifense & (Peix et al. 2015) \\
\hline Cytisus scoparius & Ochrobactrum cytisi & (Suneja et al. 2017) \\
\hline Derris elliptica & $\begin{array}{l}\text { Bradyrhizobium yuanmingense, Rhizobium } \\
\quad \text { tropici }\end{array}$ & (Bautista et al. 2017) \\
\hline Desmodium scorpiurus & $\begin{array}{l}\text { Rhizobium etli, } R \text {. rhizogenes, } \\
\text { Bradyrhizobium liaoningense, B. elkanii, } \\
\text { M. plurifarium, Rhizobium tropici, } \\
\text { Pseudomonas agglomerans }\end{array}$ & (Bautista et al. 2017) \\
\hline Desmodium styracifolium & Rhizobium etli, $R$. rhizogenes & (Bautista et al. 2017) \\
\hline Desmodium triflorum & $\begin{array}{l}\text { Bradyrhizobium, B. elkanii, B. liaoningense, } \\
\quad \text { B. yuanmingense, Rhizobium etli, } \\
\quad \text { R. tropici, R. mongolense, R. rhizogenes }\end{array}$ & (Bautista et al. 2017) \\
\hline
\end{tabular}


Table 1 (continued)

\begin{tabular}{|c|c|c|}
\hline Host & Nodule endophytes & References \\
\hline Desmodium heterocarpon & Bradyrhizobium embrapense, $B$. tropiciagri & (Suneja et al. 2017) \\
\hline Enterolobium saman & Crabtreella saccharophila, Ensifer mexicanus & (Bautista et al. 2017) \\
\hline Erythrophleum fordii & Bradyrhizobium erythrophlei, B. ferriligni & (Suneja et al. 2017) \\
\hline Galega orientalis, Galega officinalis & Neorhizobium galegae sv. orientalis & (Österman et al. 2014) \\
\hline Genista saharae & $\begin{array}{l}\text { Neorhizobium alkalisoli, } N \text {. galegae, } \\
\quad \text { N. huautlense, Mesorhizobium camelthorni }\end{array}$ & (Chaïch et al. 2017) \\
\hline Glycine $\max$ & $\begin{array}{l}\text { Acinetobacter calcoaceticus, Agrobacterium } \\
\text { tumefaciens, Bacillus amyloliquefaciens, } \\
\text { B. atrophaeus, B. cereus, B. fastidiosus, } \\
\text { B. megaterium, B. mojavensis, B. pumilus, } \\
\text { B. subtilis, B. vallismortis, Bradyrhizobium } \\
\text { ottawaense, B. daqingense, } \\
\text { B. diazoefficiens, B. elkanil, } \\
\text { B. huanghuaihaiense, B. liaoningense, } \\
\text { Burkholderia cepacia, Deinococcus } \\
\text { radiophilus, Diaphorobacter } \\
\text { ruginosibacter, Ensifer glycinis, } \\
\text { Enterobacter cloacae, Ochrobactrum } \\
\text { haematophilum, Pantoea agglomerans, } \\
\text { Paenibacillus polymyxa, Pseudomonas } \\
\text { putida, Serratia plymuthica, } \\
\text { Staphylococcus lentus, Tsukamurella } \\
\text { inchonensis }\end{array}$ & $\begin{array}{l}\text { (Sturz et al. 1997; Bai et al. 2002; Hung and } \\
\text { Annapurna 2004; Annapurna et al. 2013; } \\
\text { Pandya et al. 2013; Peix et al. 2015; } \\
\text { Velázquez et al. 2017a; Zhao et al. 2017) }\end{array}$ \\
\hline Gueldenstaedtia multiflora & Rhizobium yanglingense & (Peix et al. 2015) \\
\hline Hedysarum coronarium & Rhizobium sullae & (Peix et al. 2015) \\
\hline $\begin{array}{l}\text { Hedysarum spinosissimum, } \\
\text { H. glomeratum }\end{array}$ & $\begin{array}{l}\text { Enterobacter agglomerans, E. kobei, Erwinia } \\
\text { persicina, Escherichia vulneris, Lecrercia } \\
\text { adecarboxylata, Pantoea agglomerans, } \\
\text { Pantoea ananatis, Phyllobacterium } \\
\text { myrsinacearum, Pseudomonas corrugata, } \\
\text { Staphylococcus pasteuri, Xanthomonas } \\
\text { translucens }\end{array}$ & $\begin{array}{l}\text { (Sturz et al. 1997; Muresu et al. 2008; Pandya } \\
\text { et al. 2013; Martínez-Hidalgo and Hirsch } \\
\text { 2017) }\end{array}$ \\
\hline H. multijugum & Rhizobium hedysari & (Xu et al. 2017) \\
\hline H. polybotrys & $\begin{array}{l}\text { Mesorhizobium tianshanense, } \\
\text { M. septentrionale }\end{array}$ & (Yan et al. 2016) \\
\hline Hedysarum spinosissimum & Xanthomonas maltophilia & (Arone et al. 2014) \\
\hline Hippophae rhamnoides & $\begin{array}{l}\text { Micromonosporae chaiyapumensis, } \\
\text { M. chersina, } \text { M. coxensis, } \text { M. equina, } \\
\text { M. lupini, M narathiwatensis, } \\
\text { M. saelicesensis, } \text { M. siamensis, } \\
\text { M. viridifaciens }\end{array}$ & (Trujillo et al. 2014) \\
\hline Indigofera spicata & Rhizobium vallis & (Peix et al. 2015) \\
\hline Inga edulis, I. laurina, Inga sp. & Bradyrhizobium inga, B. forestalis & (Martins da Costa et al. 2018) \\
\hline Kummerowia stipulacea & $\begin{array}{l}\text { Rhizobium cauense, } R \text {. indigoferae, Shinella } \\
\quad \text { kummerowiae }\end{array}$ & $\begin{array}{l}\text { (Lin et al. 2008; Peix et al. 2015; Suneja et al. } \\
\text { 2017) }\end{array}$ \\
\hline Kummerowia striata & $\begin{array}{l}\text { Allorhizobium taibaishanense, Rhizobium } \\
\text { taibaishanense }\end{array}$ & (Peix et al. 2015) \\
\hline Lathyrus maritimus & Rhizobium anhuiense & (Li et al. 2016b) \\
\hline Lathyrus numidicus & Phyllobacterium ifriqiyense & (Li et al. 2016b) \\
\hline Lebeckia ambigua & Burkholderia dilworthii, B. sprentiae & (Suneja et al. 2017) \\
\hline Lens culinaris & Rhizobium bangladeshense, $R$. binae, $R$. lentis & (Velázquez et al. 2017a) \\
\hline
\end{tabular}


Table 1 (continued)

\begin{tabular}{|c|c|c|}
\hline Host & Nodule endophytes & References \\
\hline Lespedeza cuneata & Bradyrhizobium yuanmingense & (Peix et al. 2015) \\
\hline Lespedeza sp. & $\begin{array}{l}\text { Arthrobacter nitroguaiacolicus, Bacillus } \\
\text { megaterium, Burkholderia caledonica, } \\
\text { B. glathei, B. phenazinium, } \\
\text { B. phytofirmans, B. sediminicola, } \\
\text { B. sordidicola, Dyella japonica, } \\
\text { D. koreensis, D. marensis, } \\
\text { Methylobacterium fujisawaense, Rhizobium } \\
\text { miluonense, Staphylococcus warneri }\end{array}$ & $\begin{array}{l}\text { (Gu et al. 2008; Palaniappan et al. 2010; } \\
\text { Martínez-Hidalgo and Hirsch 2017) }\end{array}$ \\
\hline Leucaena leucocephala & Sinorhizobium morelense & (Suneja et al. 2017) \\
\hline Listia angolensis, Lupinos texensis & $\begin{array}{l}\text { Microvirga lotononidis, M. lupini, } \\
\text { M. zambiensis }\end{array}$ & (Martínez-Hidalgo and Hirsch 2017) \\
\hline Lotononis bainesii & Methylobacterium nodulans & (Suneja et al. 2017) \\
\hline Lotus berthelotii & Mesorhizobium tamadayense & (Peix et al. 2015) \\
\hline Lotus corniculatus & $\begin{array}{l}\text { Mesorhizobium erdmanii, M. jarvisii, } \\
\quad \text { Rhodococcus strains }\end{array}$ & $\begin{array}{l}\text { (Martínez-Hidalgo and Hirsch 2017; Suneja } \\
\text { et al. 2017) }\end{array}$ \\
\hline Lotus arabicus, Lotus creticus & Ensifer numidicus & (Suneja et al. 2017) \\
\hline Lotus frondosus & Mesorhizobium tarimense & (Peix et al. 2015) \\
\hline Lupinus albus & Cohnella lupini, Paenibacillus lupini & (Flores-Felix et al. 2014) \\
\hline Lupinus angustifolius & $\begin{array}{l}\text { Micromonospora aurantiaca, } \text { M. auratinigra, } \\
\text { M. chaiyapumensis, } \text { M. coriariae, } \\
\text { M. coxensis, } \text { M. echinospora, } \\
\text { M. fulviviridis, } \text { M. lupini, } \\
\text { M. matsumotoense, M. narathiwatensis, } \\
\text { M. olivasterospora, M. sagamiensis, } \\
\text { M. saelicesensis }\end{array}$ & (Trujillo et al. 2014) \\
\hline L. gredensis & $\begin{array}{l}\text { Micromonospora chaiyapumensis, } \\
\text { M. chersina, M. coxensis, M. echinofusca, } \\
\text { M. echinospora, M. lupini, } \\
\text { M. olivasterospora, M. saelicesensis, } \\
\text { M. viridifaciens }\end{array}$ & (Trujillo et al. 2014) \\
\hline Lupinus hon & Ochrobactrum lupine & (Carro et al. 2014; Suneja et al. 2017) \\
\hline Lupinus mariae-josephae & Bradyrhizobium valentinum & \\
\hline Lupinus texensis & Microvirga lupini & (Ardley et al. 2012) \\
\hline Macroptilium lathyroides & $\begin{array}{l}\text { Rhizobium etli, } R \text {. rhizogenes, } \\
\text { Bradyrhizobium elkanii, B. liaoningense, } \\
\text { B. yuanmingense, Pleomorphomonas } \\
\text { oryzae }\end{array}$ & (Bautista et al. 2017) \\
\hline Medicago hispida & Ensifer medicae & (Arone et al. 2014) \\
\hline Medicago lupulina & Pseudomonas brassicacearum & (Kong et al. 2017) \\
\hline Medicago ruthenica & Rhizobium alamii, $R$. mongolense & (Suneja et al. 2017) \\
\hline Medicago sativa & Bacillus megaterium, Endobacter medicaginis & $\begin{array}{l}\text { (Khalifa and Almalki 2015; Ramírez-Bahena } \\
\text { et al. 2016) }\end{array}$ \\
\hline $\begin{array}{l}\text { Mimosa acutistipula, M. adenocarpa, } \\
\text { M. bahamensis, } \text { M. blanchetii, } \\
\text { M. delicatula, } \text { M. diplotricha, } \\
\text { M. flocculosa, M. luisana, } \\
\text { M. polyantha, M. pigra }\end{array}$ & $\begin{array}{l}\text { Burkholderia phymatum, Cupriavidus } \\
\text { taiwanenis }\end{array}$ & (Elliott et al. 2007) \\
\hline Mimosa flocculosa & Burkholderia phenoliruptrix & (Zuleta et al. 2014) \\
\hline
\end{tabular}


Table 1 (continued)

\begin{tabular}{|c|c|c|}
\hline Host & Nodule endophytes & References \\
\hline & $\begin{array}{l}\text { Burkholderia mimosarum, B. nodosa, } \\
\text { B. phymatum, B. tuberum, Cupriavidus } \\
\text { taiwanensis, } R \text {. vallis, Pseudomonas } \\
\text { agglomerans }\end{array}$ & $\begin{array}{l}\text { (Peix et al. 2015; Bautista et al. 2017; Suneja } \\
\quad \text { et al. 2017) }\end{array}$ \\
\hline Morella pensylvanica & $\begin{array}{l}\text { Micromonosporae coriariae, } \text { M. cremea, } \\
\text { M. olivasteraspora, } M \text {. peucetia, } \\
\text { M. saelicesensis }\end{array}$ & (Trujillo et al. 2014) \\
\hline Myrica gale & Micromonosporae lupini, M. tulbaghiae & (Trujillo et al. 2014) \\
\hline Neonotonia wightii & Bradyrhizobium embrapense, B. tropiciagri & (Suneja et al. 2017) \\
\hline Neptunia natans & $\begin{array}{l}\text { Allorhizobium undicola, Devosia neptuniae, } \\
\text { Rhizobium tubonense }\end{array}$ & (Suneja et al. 2017) \\
\hline Ononis tridendata & Phyllobacterium trifolii & $\begin{array}{l}\text { (Rivas et al. 2002; Martínez-Hidalgo and } \\
\text { Hirsch 2017) }\end{array}$ \\
\hline Ornithopus pinnatus & $\begin{array}{l}\text { Curtobacterium flaccumfaciens, C. herbarum, } \\
\text { Enterobacter agglomerans }\end{array}$ & (Muresu et al. 2008) \\
\hline Oxytropis glabra & Rhizobium tubonense & (Peix et al. 2015) \\
\hline Oxytropis cashemiriana & Pararhizobium herbae & (Velázquez et al. 2017a, b) \\
\hline Oxytropis glabra & Mesorhizobium gobiense & (Peix et al. 2015) \\
\hline Tetragonolobus purpureus & $\begin{array}{l}\text { Staphylococcus epidermidis, Staphylococcus } \\
\text { pasteuri }\end{array}$ & (Sturz et al. 1997; Muresu et al. 2008) \\
\hline Trifolium pratense & $\begin{array}{l}\text { Bacillus brevis, B. insolitus, B. megaterium, } \\
\text { B. subtilis, Bortedella avium, } \\
\text { Curtobacterium citreum, } \\
\text { C. flaccumfaciens, C. luteum, } \\
\text { Methylobacterium extorquens, } \\
\text { Pseudomonas fragi, Ps. lini, Ps. putida, Ps. } \\
\text { viridiflava, Roseateles depolymerans }\end{array}$ & (Sturz et al. 1997; Muresu et al. 2008) \\
\hline Pachyrhizus erosus & Bradyrhizobium jicamae, B. pachyrhizi & (Suneja et al. 2017) \\
\hline Phaseolus lunatus & $\begin{array}{l}\text { Bradyrhizobium icense, } B . \text { paxllaeri, } \\
\quad \text { Rhizobium endophyticum, } R \text {. hidalgonense }\end{array}$ & (Li et al. 2016a; Velázquez et al. 2017a) \\
\hline Phaseolus vulgaris & $\begin{array}{l}\text { Agrobacterium pusense, Bradyrhizobium } \\
\text { paxllaeri, Cohnella phaseoli, Cupriavidus } \\
\text { necátor, Enterobacter hormaechei, } \\
\text { Fontibacillus phaseoli, Herbaspirillum } \\
\text { lusitanum, Klebsiella pneumoniae, } \\
\text { Micromonosporae chaiyapumensis, } \\
\text { M. chersina, M. endolithica, } \\
\text { Pararhizobium giardinii, Phyllobacterium } \\
\text { endophyticum, Providencia rettgeri, } \\
\text { Pseudomonas koreensis, Rhizobium } \\
\text { azibense, R. ecuadorense, R. lusitanum, } \\
\text { R. paranaense, } R \text {. vallis, R. acidisoli, } \\
\text { Xiangella phaseoli }\end{array}$ & $\begin{array}{l}\text { (López-López et al. 2010; Trujillo et al. 2015; } \\
\text { Peix et al. 2015; Aguilar et al. 2016; Suneja } \\
\text { et al. 2017; Velázquez et al. 2017a; Wekesa } \\
\text { et al. 2017) }\end{array}$ \\
\hline Pisum sativum & $\begin{array}{l}\text { Bacillus simplex, Micromonosporae } \\
\text { aurantica, M. auratinigra, } \\
\text { M. chaiyapumensis, M. chersina, } \\
\text { M. coerulea, M. coriariae, M. coxensis, } \\
\text { M. fulviviridis, M. lupini, } \\
\text { M. matsumotoense, M. pattaloongensis, } \\
\text { M. saelicesensis, M. sagamiensis, } \\
\text { M. siamensis, M. phytophila, } \\
\text { M. luteiviridis, Rhizobium pisi }\end{array}$ & $\begin{array}{l}\text { (Trujillo et al. 2015; Peix et al. 2015; } \\
\text { Martínez-Hidalgo and Hirsch 2017; Carro } \\
\text { et al. 2017) }\end{array}$ \\
\hline Pongamia pinnata & Rhizobium pongamiae & (Suneja et al. 2017) \\
\hline
\end{tabular}


Table 1 (continued)

\begin{tabular}{|c|c|c|}
\hline Host & Nodule endophytes & References \\
\hline Prosopis alba & Mesorhizobium chacoense & (Suneja et al. 2017) \\
\hline Prosopis chilensis & Ensifer arboris, E. kostiensis & (Peix et al. 2015; Suneja et al. 2017) \\
\hline Prosopis juliflora & Achromobacter xylosoxidans & (Arone et al. 2014) \\
\hline Psophocarpus tetragonolobus & $\begin{array}{l}\text { Bradyrhizobium elkanii, B. yuanmingense, } \\
\text { Rhizobium rhizogenes, Stenotrophomonas } \\
\text { maltrophilia }\end{array}$ & (Bautista et al. 2017) \\
\hline Psoralea corylifolia & Ensifer psoraleae & (Peix et al. 2015) \\
\hline Pterocarpus indicus & $\begin{array}{l}\text { Bradyrhizobium liaoningense, } B \text {. japonicum, } \\
\text { Ensifer adhaerens, Labrys neptuniae, } \\
\text { Rhizobium lusitanum, R. rhizogenes, } \\
\text { R. tropici }\end{array}$ & (Bautista et al. 2017) \\
\hline Pueraria candollei & Rhizobium puerariae & (Boonsnongcheep et al. 2016) \\
\hline Pueraria lobata & Devosia yakushimensis & (Bautista et al. 2010) \\
\hline Pueraria thunbergiana & $\begin{array}{l}\text { Bacillus thuringiensis, Enterobacter asburiae, } \\
\text { Serratia marcescens }\end{array}$ & (Selvakumar et al. 2008) \\
\hline Retama monosperma, $R$. sphaerocarpa & Bradyrhizobium rifense & (Suneja et al. 2017) \\
\hline Robinia pseudoacacia & Mesorhizobium robiniae & (Suneja et al. 2017) \\
\hline Samanea saman & $\begin{array}{l}\text { Bradyrhizobium japonicum, B. liaoningense, } \\
\text { Labrys neptuniae, Pantoea } \mathrm{sp.}\end{array}$ & (Bautista et al. 2017) \\
\hline Scorpiurus muricatus & $\begin{array}{l}\text { Phyllobacterium endophyticum, } P \text {. ifriqiyense, } \\
\text { Pseudomonas brenneri, Rhizobium } \\
\text { nepotum, R. radiobacter, R. vignae, } \\
\text { Starkeya novella }\end{array}$ & (Bouchiba et al. 2017) \\
\hline Sophora flavescens & Rhizobium sophorae, R. sophoriradicis & (Velázquez et al. 2017a) \\
\hline Sophora longicarinata & Mesorhizobium calcicola, M. waimense & (de Meyer et al. 2016) \\
\hline Sophora microphylla & $\begin{array}{l}\text { Mesorhizobium cantuariense, } M . \text { kowhaii, } \\
\text { M. sophorae, } M \text {. waitakense }\end{array}$ & (de Meyer et al. 2016; Velázquez et al. 2017a) \\
\hline Sophora prostrata & Mesorhizobium newzealandense & (de Meyer et al. 2016) \\
\hline Sesbania cannabina & $\begin{array}{l}\text { Agrobacterium deltaense, A. salinitolerans, } \\
\text { Ensifer psoraleae, Rhizobium radiobacater }\end{array}$ & $\begin{array}{l}\text { (Peix et al. 2015; Martínez-Hidalgo and } \\
\text { Hirsch 2017; Yan et al. 2017a, b) }\end{array}$ \\
\hline Sesbania herbacea & Neorhizobium huautlense & (Li et al. 2016a) \\
\hline Sesbania rostrata & Azorhizobium caulinodans, Ensifer indiaense & (Suneja et al. 2017) \\
\hline Sesbania sesban & $\begin{array}{l}\text { Agrobacterium tumefaciens, Pseudomonas } \\
\text { geniculata, Pantoea agglomerans }\end{array}$ & (Hossain and Lundquist 2016) \\
\hline Sesbania virgata & Azorhizobium doebereineraee & (Suneja et al. 2017) \\
\hline Sophora alopecuroides & Bacillus cereus, Pseudomonas chlororaphis & (Zhao et al. 2011, 2013) \\
\hline Sphaerophysa salsula & $\begin{array}{l}\text { Bacillus safensi, B. simplex, Brevibacillus } \\
\text { borstelensis, Inquilinus limosus, } \\
\text { Lysinibacillus fusiformis, Mesorhizobium } \\
\text { amorphae, M. gobiens, M. tianshanense, } \\
\text { Nocardia uniformis, Paenibacillus } \\
\text { amylolyticus, Paracoccus halophilus, } \\
\text { Pararhizobium sphaerophysae, } \\
\text { Pseudomonas fluorescens, Rhizobium } \\
\text { giardinii, R. helanshanense, } \\
\text { R. sphaerophysae, Serratia plymuthica, } \\
\text { Sphingomonas pruni, Streptomyces } \\
\text { bottropensi }\end{array}$ & $\begin{array}{l}\text { (Deng et al. 2011; Peix et al. 2015; Velázquez } \\
\text { et al. 2017a) }\end{array}$ \\
\hline
\end{tabular}

Sulla capitata

Rhizobium nepotum, Pseudomonas fluorescens, Variovorax paradoxux

(Beghalem et al. 2017) 
Table 1 (continued)

\begin{tabular}{|c|c|c|}
\hline Host & Nodule endophytes & References \\
\hline Sulla pallida & $\begin{array}{l}\text { Neorhizobium galegae, Phyllobacterium } \\
\text { ifriqiyense, Pseudomonas fluorescens, } \\
\text { Rhizobium nepotum }\end{array}$ & (Beghalem et al. 2017) \\
\hline Trifolium alexandrinum & Rhizobium aegyptiacum & (Velázquez et al. 2017a) \\
\hline Trigonella archiducis-nicolai & Rhizobium tibeticum & (Peix et al. 2015) \\
\hline Vicia alpestris & Microvirga ossetica & (Safronova et al. 2017) \\
\hline Vicia faba, Pisum sativum & Rhizobium anhuiense & (Velázquez et al. 2017a) \\
\hline V. faba & $\begin{array}{l}\text { Accumulibacter phosphatis, Acinetobacter } \\
\text { woffii, Alcaligenes faecalis, Bacillus } \\
\text { megaterium, B. muralis, B. subtilis, } \\
\text { Brevibacterium luteolum, Bukholderia } \\
\text { phytofirmans, B. xenovorans, } \\
\text { B. verschuerenii, Calditerrivibrio } \\
\text { nitroreducens, Chlorobium leteolum, } \\
\text { Dechloromonas aromatica, Deinococcus } \\
\text { maricopensis, Desulfovibrio desulfuricans, } \\
\text { Enterobacter amnigenus, E. cancerogenus, } \\
\text { Geobacater uraniireducens, Nitrosopira } \\
\text { multiformis, Pantoea agglomerans, } \\
\text { P. brenneri, P. marginalis, Phyllobacterium } \\
\text { trifolii, Pseudomonas aeuroginosa, } \\
\text { P. fluorescens, Rhizobium aquatilis, } \\
\text { R. grahamii, R. leguminosarum, } \\
\text { R. nepotum, } R \text {. pusense, } R \text {. radiobacter, } \\
\text { Serratia maltophilia, S. odorifera, } \\
\text { Staphylococcus saprophyticus, } \\
\text { Symbiobacterium thermophilum, } \\
\text { Synechococcus elongatus, Variovorax } \\
\text { paradoxus, Verminephrobacter eiseniae, } \\
\text { Xanthomonas campestris }\end{array}$ & (Saïdi et al. 2013; Trabelsi et al. 2017) \\
\hline Vigna mungo & Bacillus mycoides, Klebsiella pneumoniae & (Hossain and Lundquist 2016) \\
\hline V. radiata & $\begin{array}{l}\text { Agrobacterium tumefaciens, A. vitis, Bacillus } \\
\text { anthracis, B. circulans, B. endophyticus, } \\
\text { B. mojavensis, B. safensis, B. sonorensis, } \\
\text { B. pumilus, Blastobacter aggregatus, } \\
\text { Chitinophaga filiformis, Chryseobacterium } \\
\text { indologenes, Cupriavidus necátor, } \\
\text { Dyadobacter fermentans, Ensifer } \\
\text { adhaerens, Klebsiella pneumoniae, } \\
\text { Macrophomina phaseolina, Paenibacillus } \\
\text { amylolyticus, P. barciconensis, P. circulans, } \\
\text { P. kribbensis, P. macquariensis, } \\
\text { P. massiliensis, P. pabuli, P. panacisoli, } \\
\text { P. taichungensis, P. validus, } \\
\text { P.xylanexedens, P. xylanilyticus }\end{array}$ & $\begin{array}{l}\text { (Pandya et al. 2015; Suneja et al. 2017; Harsha } \\
\text { Shelat and Panpatte 2017) }\end{array}$ \\
\hline V. subterranea & $\begin{array}{l}\text { Bradyrhizobium kavangense, } \\
\text { B. subterraneum, B. vignae, Burkholderia } \\
\text { cenocepacia }\end{array}$ & (Grönemeyer et al. 2016; Bautista et al. 2017) \\
\hline V. unguiculata & Bradyrhizobium manausense, $B$. vignae & $\begin{array}{l}\text { (Grönemeyer et al. 2016; Simões-Araújo et al. } \\
\text { 2017) }\end{array}$ \\
\hline Virgilia oroboides & Paraburkholderia kirstenboschensis & (Steenkamp et al. 2015) \\
\hline
\end{tabular}


dextrorotatory $(S)$-allantoin catalyzed by the enzyme OHCU decarboxylase in, i.e., B. subtilis, E. coli, Herbaspirillum seropedicae, Klebsiella spp., and Ruegeria pomeroyi TB-90 (Matiollo et al. 2009; Doniselli et al. 2015; Cunliffe 2016; Hafez et al. 2017). The fourth step underlies the conversion of $(S)$ allantoin into allantoate by the enzyme $(S)$-allantoin amidohydrolase (allantoinase) (Werner and Witte 2011). There is also the possibility of a spontaneous racemization of $(S)$-allantoin to its $(R)$-enantiomer at an estimated rate constant of $\sim 2 \times 10^{-5}$ at neutral $\mathrm{pH}$ (Cendron et al. 2016). Therefore, to ensure the overall efficiency of the catabolic pathway, the $(R)$-allantoin enantiomer is converted into $(S)$-allantoin by the enzyme allantoin racemase, as recorded in K. pneumoniae, Pseudomonas fluorescens, Ps. putida, Ps. testosteroni, and Proteus rettgeri (van der Drift et al. 1975; Cendron et al. 2016; Danchin 2017) to prevent the accumulation of $(R)$-allantoin.

Direct interactions between the purine metabolism and the bacteria IAA production and/or ACCD activity can be extrapolated from $(i)$ the increased ureide content in plants treated with 1-methyl cyclopropene, a known inhibitor of ethylene synthesis (Do Nascimento et al. 2016), and (ii) the upregulation of the nitrogenase activity inside root nodules of drought stressed Medicago sativa plants inoculated with the IAA-overproducing Ensifer meliloti strain Ms-RD64 (Defez et al. 2017).

Overview of the main enzymes and genes involved in the bacterial synthesis of ureides

The enzyme guanine deaminase belongs to the cytidine (hence a pyrimidine) deaminase superfamily, with marked structural differences with the same enzyme in E. coli (Danchin 2017). The enzyme XDH is a NAD ${ }^{+}$cofactor xanthine $\mathrm{FAD} /$ molybdopterin-dependent dehydrogenase as reported in Acinetobacter baumannii (Wang et al. 2015), Rhodobacter capsulatus (Reschke et al. 2017), Pseudomonas acidovorans, Ps. aeruginosa, Ps. aureofaciens, Ps. cepacia, Ps. putida, Ps. testosteroni (Woolfolk and Downard 1977), and Streptomyces coelicolor (Sivapragasam and Grove 2016). In most bacteria, XDH activity diverts the hypoxanthine and xanthine from the purine salvage pathway. However, in $S$. coelicolor as well as in the soil and plant colonizing Listeria monocytogenes, the $\mathrm{XDH}$ is involved mainly in the purine salvage catabolic pathway needed to generate sufficient GDP and GTP, the substrates for the phosphorylated nucleosides guanosine $5^{\prime}$ (di)triphosphate 3 'diphosphate synthetases (Sivapragasam and Grove 2016), via the XDH transcriptional repressor (xdhR) with a binding site to either GTP or ppGpp transcriptional repressor to induce $\mathrm{xdhABC}$ expression. As far as we could verify, there is only one publication on the inhibitory effects of plant phenolics and flavonoids from Juniperus procera on the XO activity in Gram-positive bacteria (Samaha et al. 2017), contrasting with the large number of clinical reports showing the inhibitor effects of plant isoflavones and flavonol glycosides on the XO and/or UOX activities in bacteria pathogens to animals and humans (Nile et al. 2017; Raziq et al. 2017). Extrapolating from data published by Cantu-Medellin and Kelley (2013), there is a possibility that reduction of $\mathrm{NO}_{3}{ }^{-}$to peroxynitrite via the $\mathrm{XO}$ could take place by $\mathrm{PAB}$ in plants grown in low soil $\mathrm{pH}$ or in seasonally flooded soils with fluctuating $\mathrm{O}_{2}$ and $\mathrm{NO}_{3}{ }^{-}$availability. The detour of xanthine from the ureide synthesis via the purine salvage pathway in $B$. subtilis is catalyzed by the enzyme $\mathrm{Mg}^{2+}$-dependent xanthine phosphoribosyl transferase resulting in the synthesis of xanthosine-5'monophosphate (Del Arco et al. 2017), under the control of the guanine-binding xpt riboswitch (Kirchner and Schneider 2017). In parallel, XDH was reported to actively participate in the stringent (stress) response in the $\mathrm{N}_{2}$-fixing S. meliloti (Krol and Becker 2011). On the other hand, the activity of the enzyme XO, catalyzes in B. pumilus (Sharma et al. 2016) and Arthrobacter sp. strain MU12 (Li et al. 2017), the oxidation of hypoxanthine to xanthine and uric acid with the concomitant reduction of $\mathrm{O}_{2}$ to $\mathrm{H}_{2} \mathrm{O}_{2}$ and $\mathrm{O}_{2}{ }^{-}$categorized as central redox signaling molecules. On the other hand, the intracellular location of UOX was reported in B. fastidious, B. subtilis RNZ-79, B. pasteurii, P. mirabilis, and E. coli, while extracellular production of UOX was observed in S. albosriseolus, S. graminofaciens, S. albidoflavus, Microbacterium sp., and Ps. aeruginosa (Zhao et al. 2006; Khade and Srivastava 2016; Kotb 2016; Hafez et al. 2017). Uric acid was shown to be the main inducer of UOX in B. cereus, B. thermocatenulatus, $S$. albosriseolus, Sphingobacterium thalpophilum, S. exfoliates, S. graminofaciens, and S. albidoflavus (Nanda and Jagadeesh Babu 2014). In general, UOX was categorized as a thermosensitive and co-factorindependent enzyme. However, a thermostable $\mathrm{Mg}^{2+}$ co-factor UOX was identified in B. firmus isolated from soils (Kotb 2016). On the other hand, UOX activity in Ps. aeruginosa was triggered by $\mathrm{Ca}^{2+}$, but inhibited by 
$\mathrm{Co}^{2+}, \mathrm{Mn}^{2+}, \mathrm{Mg}^{2+}, \mathrm{Fe}^{2+}, \mathrm{Zn}^{2+}$, and $\mathrm{Cu}^{2+}$ in the growing media (Amirthanathan and Vijayakumar 2011), contrasting with the $\mathrm{Ca}^{2+}, \mathrm{Mn}^{2+}, \mathrm{Mg}^{2+}$, and $\mathrm{Fe}^{2+}$ stimulation of the intracellular UOX in S. exfoliates (Aly et al. 2013). While, the extracellular activity of UOX from S. thalpophilum was enhanced by $\mathrm{Cu}^{2+}$ but partially inhibited by $\mathrm{Ca}^{2+}, \mathrm{Fe}^{2+} \mathrm{Zn}^{2+}$, and $\mathrm{Ni}^{2+}$ (Ravichandran et al. 2015). Details of the conversion of uric acid to HIU by the FAD-dependent UOX in $K$. pneumoniae were described by Hicks et al. (2013). The enzyme allantoinase belongs to the cyclic amidohydrolases family, possesses a binuclear metal center in the active site, and in certain bacterial species, it can be inhibited by the flavonol kaempferol (Peng and Huang 2014). The most effective co-factors of allantoinase are $\mathrm{Zn}^{2+}$ and $\mathrm{Co}^{2+}$ in E. coli, $\mathrm{Mn}^{2+}$ in Streptococcus allantoicus and Arthrobacter allantoicus, and $\mathrm{Co}^{2+}$ in B. licheniformis CECT 20T that shows an apparent unique inverted enantioselectivity towards $(R)$-allantoin (MartínezGómez et al. 2014); while in E. coli and Pseudomonas species, it is inhibited by $\mathrm{Mn}^{2+}$ (Werner and Witte 2011).

Under N-limited availability, B. subtilis grown aerobically expresses the full set of genes encoding the synthesis of allantoin (Ma et al. 2016). Similar nutrient conditions trigger the oxidation of hypoxanthine to allantoin in K. pneumoniae codified by the hpx cluster of seven genes organized in four transcriptional units: hpxDE, hpxR, hpxO, and hpxPQT (De La Riva et al. 2008). Details on the XDH encoding genes $x d h A, x d h B$, and $x d h C$ corresponding to the small subunit (XDHA), the large subunit (XDHB), and the chaperone protein (XDHC) were published by Wang et al. (2015). It is interesting to note that the $\mathrm{XDH}$ encoding gene in $R$. capsulatus is not under the control of $\mathrm{N}$ regulatory network but induced by xanthine (Leimkühler et al. 1998). The genes encoding the enzymes UOX and allantoinase were described in $H$. seropedicae by Matiollo et al. (2009), whereas, the upregulation of genes encoding the enzyme guanine deaminase (msmeg_1298), uricase (msmeg_1296), transthyretin (msmeg_1295), and 2-oxo-4-hydroxy-4-carboxy-5ureidoimidazoline decarboxylase (msmeg_1294) was reported in N-limited Mycobacterium smegmatis (Petridis et al. 2015). Divergently oriented genes encoding UOX and the transcriptional regulator HucR were reported in Deinococcus radiodurans (Wilkinson and Grove 2005). Interestingly, the E. coli K-12 genome encodes the uric acid permease activity (YgfU), in spite of the lack of all enzymes for uric acid catabolism
(Papakostas and Frillingos 2012). As additional information, allantoin is also synthesized in the endophytic fungus Fusarium sp. isolated from the roots of Astragalus membranaceus and leaves of Eucommia ulmoides, in the endophytic fungi Aspergillus sp. and Chaetomium globosum isolated from Eucommia ulmoides and Ginko biloba, respectively (Zhang et al. 2015), and in a mangrove endophyte fungus ZSU-H19 from the South China Sea (Sharples and Cairney 1997; Zhang et al. 2012), but not in Aspergillus terreus from Artemisia annua (Sun 2009; Zhang et al. 2015).

\section{Bacterial ureide catabolism}

The catabolism of allantoate to $\mathrm{NH}_{3}$ might proceed via two metabolic routes depending on the bacterial species (Fig. 1). The route 1, i.e., in Ps. acidovorans, $R$. pomeroyi, $S$. coelicolor, and in N-limited $M$. smegmatis, starts with the conversion of $(S)$ allantoate to $(S)$-ureidoglycolate by the $\mathrm{Mn}^{2+}$-dependent enzyme allantoicase, to be finally hydrolyzed to glyoxylate and $\mathrm{NH}_{4}{ }^{+}$in a reaction catalyzed by the enzyme ureidoglycolate lyase in Burkholderia cepacia, E. coli, Lactobacillus buchneri, Methylobacterium nodulans, M. radiotolerants, Pseudomonas sp., and Streptococcus sp. (Raymond et al. 2005; Liu 2014; Minami et al. 2016), or to glyoxylate and $2 \mathrm{NH}_{3}$ via the enzymatic reaction catalyzed by the ureidoglycolate amidohydrolase in E. coli $\mathrm{O} 157: \mathrm{H} 7$ and R. pomeroy (Serventi et al. 2010; Werner et al. 2010; Cunliffe 2016). The route 2 commences with the conversion of $(S)$-allantoate to $(S)$-ureidoglycine by the enzyme allantoate amidohydrolase and into oxalurate via the reaction catalyzed by the enzyme $\mathrm{Mn}^{2+}-\mathrm{Co}^{2+}$, and $\mathrm{Ni}^{2+}$-dependent $(S)$-ureidoglycine aminotransferase, concomitantly with the synthesis of $\alpha$-amino acids from $\alpha$-keto acids (French and Ealick 2010). The further degradation of oxalurate to carbamoyl phosphate and oxamate is catalyzed by the enzyme oxamate carbamoyl transferase in E. coli (Hasegawa et al. 2008; Li et al. 2011) and in S. allantoicus (Bojanowski et al. 1964); in contrast to the direct conversion of oxalurate into oxamate and $\mathrm{NH}_{3}$ described in $K$. pneumoniae (Hicks and Ealick 2016). Oxamate is finally converted to oxalate by the enzyme oxamate amidohydrolase as shown in K. pneumoniae (Hicks and Ealick 2016; Danchin 2017). On the other hand, the report of S. faecalis ATCC 11700 being capable to metabolize oxalurate but not allantoin 


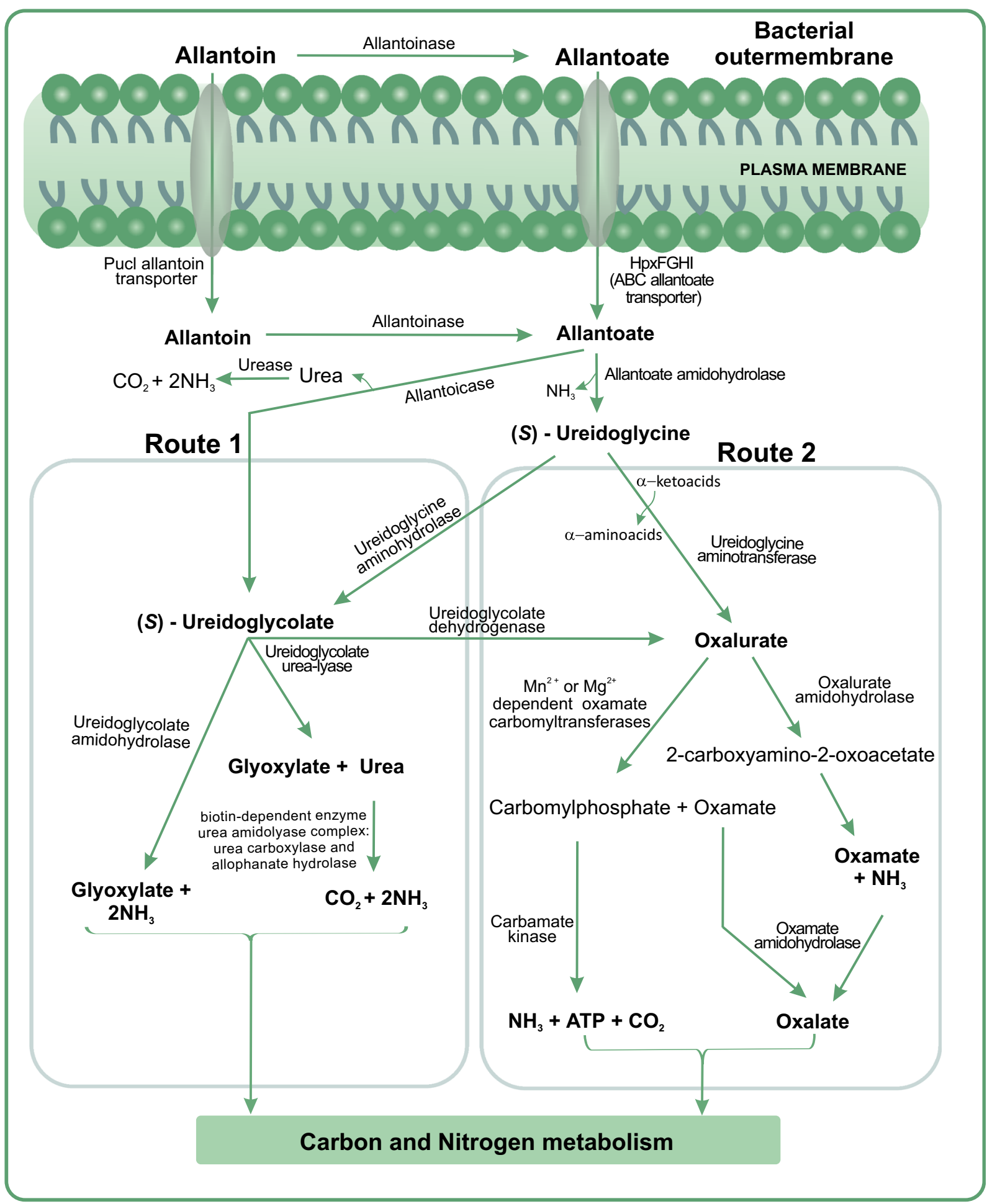

Fig. 1 Metabolic routes for the catabolism of ureides in bacteria. References for each enzymatic pathway are listed in the text. Arrows indicate the enzymatic pathways 
for growth (Vander Wauven et al. 1986) suggests the possible existence of interconnections between routes 1 and 2. As shown in E. coli, the enzyme $\mathrm{NAD}(\mathrm{P})^{+}$-dependent ureidoglycolate dehydrogenase, a member of Lsulfolactate dehydrogenase-like family, may oxidize ureidoglycolate to oxalurate, allowing urease-negative E. coli to preserve $\mathrm{N}$ and energy resources more efficiently (Werner et al. 2010). Curiously, the microbial purine pathways from allantoin to oxamate have not been a focus of research despite the use of oxamic acid thiohydrazides as precursors for the formation of hydrazones previously inaccessible from traditional hydrazones chemistry (Volkova et al. 2017).

Finally, the $\mathrm{NH}_{4}^{+}$produced in routes 1 or 2 is broken down to $\mathrm{NH}_{3}$ in either one-step reaction via urease as described in some rhizobiales bacteria (Neuvonen et al. 2016) or in a two-step reaction catalyzed by the biotindependent enzyme urea amidolyase (UAL) complex comprised by the enzymes urea carboxylase and the upregulated gene msmeg_2189 encoded allophanate hydrolase in Acetobacter pasteurianus, Granulibacter bethesdensis, Komagataeibacter nataicola, M. extorquens, M. mesophilicum, M. nodulans, M. oryzae, $M$. radiotolerans, $M$. smegmatis, Oleomonas sagaranensis, and S. avermitilis (Lin et al. 2016; Minami et al. 2016; Petridis et al. 2016; Zhang et al. 2017a). Genes encoding the enzymes allantoinase, allantoate aminohydrolase, ureidoglycolate lyase, ureidoglycolate dehydrogenase, and urease as well as for the allantoin protoncoupled symporter ( $p u c I$, also known as ALLP) and uric acid transporter (pucJK) were described in H. seropedicae (Matiollo et al. 2009), B. megaterium, B. guano, B. brevis, B. polymyxa, and B. fastidiosus (except the strain C.4) (Ma et al. 2016). The genes involved in the conversion of allantoate to oxalurate are clustered together forming the hpxFGHIJK operon in K. pneumoniae (Guzmán et al. 2013). As a curiosity, the micro algae Chlamydomonas reinhardii actively catabolize allantoin as a source of $\mathrm{N}$ via the purine catabolic pathway (Pineda et al. 1984). Examples of bacteria with or without the ability to grow on purine derivatives are listed in Table 2.

\section{Putative scenarios for purine-mediated interactions between plant and PAB}

In plants, PAB can colonize the apoplastic spaces among cortical, endodermis, and aerenchyma cells of roots, stem parenchyma, and mesophyll leaf cells, as well as the lumen of the xylem vascular system which becomes the main transport route for the systemic spread of PAB from roots (rhizosphere) to stems (laimosphere and caulosphere), leaves (phylloplane), flowers (anthosphere), fruits (carposphere), and seeds (spermosphere). The xylem not only supplies the aerial parts of the plant with water but also transports inorganic and organic forms of $\mathrm{N}$ from the root to the shoot, as in the case of $\mathrm{N}_{2}$-fixing ureidic legumes, in which ureides are the prevailing form of $\mathrm{N}$ transported in the xylem flow (Baral and Izaguirre-Mayoral 2017). Moreover, endophytes such as Azospirillum brasilense are known to enlarge the transversal area of xylem vessel in the stems of tomato plants eliciting a better diffusion and storage of substantial amounts of $\mathrm{N}$ compounds and of the better upward conduction efficiency of water (Romero et al. 2014). PAB can also colonize the sugar and N-rich phloem vessels mainly via phloem-feeding insects (Lòpez-Fernàndez et al. 2017). Therefore, it can be assumed that bacteria residing in xylem neighboring parenchyma, protoxylem, and/or phloem of underground and aboveground organs will deplete the xylem sap of specific plant-produced purine intermediaries to attenuate bacterial stress as result of seasonal drought or salinity-incited $\mathrm{N}$ deficiencies. Greater rates of purine scavenging are expected in rhizospheric and endophytic PABs lacking an active ureide metabolism, but harboring the genes related to the purine pathways modulated by riboswitches (Kirchner and Schneider 2017). In general, microbial populations harboring reversible genotypes of amino acid transporter Gap1 genes, flanked by two direct repeats that can lead to GAP1 deletions $(\triangle$ gap1) and a self-replicating GAP1 circle, have a selective advantage as purine or $\mathrm{NH}_{3}$ scavengers and thus, higher stress tolerance (Møller et al. 2013). In M. smegmatis, $\mathrm{N}$ deficiency provokes the expression of the genes involved in the uptake of $\mathrm{N}$ compounds such as xanthine/uracil permease (msmeg_2570 and msmeg_1293) as well as cytosine/purines/uracil/thiamine/allantoin permease (msmeg_5730 and msmeg_6660) (Petridis et al. 2015). On the contrary, it is possible to assume that $\mathrm{PAB}$ with active purine synthesis may benefit stress-challenged plants by supplying purine intermediaries for the synthesis of $\mathrm{NH}_{3}$ to recycle N. Massilia albidiflava, M. dura, and M. plicata isolated from soils in China are characterized as high $\mathrm{NH}_{3}$ producers (Zhang et al. 2006). To dissect these possibilities, the purine plant-microbe interactive associations were analyzed in terms of three scenarios (Fig. 2): 
Table 2 Examples of bacteria with or without the capacity to actively catabolize purine derivatives as a source of $\mathrm{N}$ for colony growth

\begin{tabular}{|c|c|c|c|c|c|}
\hline Bacteria & Xanthine & Hypoxanthine & Uric acid & Allantoin & References \\
\hline Actinopolyspora erythraea & + & & & & (Duangmal et al. 2016) \\
\hline A. xinjiangensis & + & & & & (Duangmal et al. 2016) \\
\hline Alcaligenes denitrificans & - & & & & (Martin et al. 1981) \\
\hline Aerobacter aerogenes & & & & + & (Rouf 1968) \\
\hline Aerobacter fecalis & - & & & & (Martin et al. 1981) \\
\hline Amycolatopsis eurytherma, A. thermoflava & & & & + & (Busarakam et al. 2016) \\
\hline Angustibacter peucedani & - & - & & & (Lee 2013) \\
\hline Aureimonas galii & + & - & & & (Aydogan et al. 2016) \\
\hline A. pseudogalii & + & - & & & (Aydogan et al. 2016) \\
\hline Bacillus depressus & - & + & & & (Wei et al. 2016) \\
\hline B. fastidious & & & + & $+*$ & (Azab et al. 2005) \\
\hline B. pumilus & + & & & & (Sharma et al. 2016) \\
\hline Bordetella bronchiseptica & - & & & & (Martin et al. 1981) \\
\hline Brevundimonas viscosa & - & - & & & (Wang et al. 2012) \\
\hline $\begin{array}{l}\text { Clostridium acidiurici, C. cylindrosporum, } \\
\text { C. purinolyticum }\end{array}$ & + & + & + & & (Durre et al. 1981) \\
\hline Corynebacterium glyciniphilum & & & & + & (Al-Dilaimi et al. 2015) \\
\hline Devosia insulae & - & - & & & (Yoon et al. 2007) \\
\hline Halobacillus salicampi & - & - & & & (Kim et al. 2016) \\
\hline Hydrogenomonas eutropha & & & & + & (Ammann and Reed 1967) \\
\hline Hyphomicrobium sp. (a denitrifying methylotroph) & & & & + & (van der Drift and de Windt 1983) \\
\hline Isoptericola cucumi & - & + & & & (Kämpfer et al. 2016) \\
\hline I. hypogeus & + & + & & & (Kämpfer et al. 2016) \\
\hline I. nanjingensis & + & + & & & (Kämpfer et al. 2016) \\
\hline I. variabili & + & + & & & (Kämpfer et al. 2016) \\
\hline Janibacter melonis & - & - & & & (Yoon et al. 2004) \\
\hline J. alba & + & + & & & (Qin et al. 2009) \\
\hline J. alkaliphila & - & + & & & (Lee 2008) \\
\hline J. gansuensis & - & - & & & (Lee 2008) \\
\hline Klebisella pneumoniae & & & & + & (Matiasovicova et al. 2011) \\
\hline Kocuria rosea & + & & & & (Ali et al. 2015) \\
\hline Kribbella karoonensis, K. shirazensis, K. soli & + & & & + & (Ozdemir-Kocak et al. 2017) \\
\hline $\begin{array}{l}\text { Methylobacterium aquaticum, M. platani, } \\
\text { M. tarhaniae }\end{array}$ & - & & & - & (Veyisoglu et al. 2013) \\
\hline Micromonospora yasonensis & & & & - & (Veyisoglu et al. 2016a) \\
\hline Microvirga arabica & - & & & - & (Veyisoglu et al. 2016b) \\
\hline M. makkahensis & + & & & - & (Veyisoglu et al. 2016b) \\
\hline Mucilaginibacter boryungensis & - & - & & & (Kang et al. 2011) \\
\hline Nocardia aciditolerans & & & & - & (Golinska et al. 2013) \\
\hline N. alba & & & & - & (Camas et al. 2017) \\
\hline N. caishijiensis & & & & - & (Camas et al. 2017) \\
\hline N. goodfellowii & & & & - & (Camas et al. 2017) \\
\hline
\end{tabular}


Table 2 (continued)

\begin{tabular}{|c|c|c|c|c|c|}
\hline Bacteria & Xanthine & Hypoxanthine & Uric acid & Allantoin & References \\
\hline N. sungurluensis & & & & + & (Camas et al. 2017) \\
\hline Nonomuraea muscovyensis & & & & - & (Ozdemir-Kocak et al. 2014) \\
\hline Paraburkholderia tropica & & & & + & (Silva et al. 2017b) \\
\hline Pedobacter sandarakinus & - & - & & & (Yoon et al. 2006) \\
\hline Peptococcus prevotii & + & & & & (Reece et al. 1976) \\
\hline Phenylobacterium composti & - & - & & & (Weon et al. 2008) \\
\hline Pseudomonas acidovorans & + & & & & (Martin et al. 1981) \\
\hline Ps. alcaligenes & + & & & & (Martin et al. 1981) \\
\hline Ps. aeruginosa & & & & + & (Rouf 1968) \\
\hline Ps. diminuta & - & & & & (Martin et al. 1981) \\
\hline Ps. mesoacidophila & & & & + & (Loveridge et al. 2017) \\
\hline Ps. pseudoalcaligenes & - & & & & (Martin et al. 1981) \\
\hline Ps. putida & + & + & + & + & (Fernández et al. 2016) \\
\hline Ps. putrefaciens & + & & & & (Martin et al. 1981) \\
\hline Ps. testosteroni & + & & & & (Martin et al. 1981) \\
\hline Ruania albidiflava & - & - & & & (Gu et al. 2007) \\
\hline Salmonella enterica & & & & + & (Matiasovicova et al. 2011) \\
\hline Serratia kiliensis & & & & + & (Rouf 1968) \\
\hline Streptomonospora tuzyakensis & - & & & - & (Tatar et al. 2016) \\
\hline Staphylococcus flavocyaneus & & + & & & (Aaronsoni 1955) \\
\hline Streptomyces albidoflavus & - & & & - & (Gupta et al. 2009) \\
\hline S. aridus & & & + & - & (Idris et al. 2017) \\
\hline S. atroolivaceus & + & & & + & (Gupta et al. 2009) \\
\hline S. aurantiacus & - & & & + & (Gupta et al. 2009) \\
\hline S. avicennia & - & & & - & (Saricaoglu et al. 2014) \\
\hline S. brevispora & & & & + & (Zucchi et al. 2012) \\
\hline S. burgazadensis & - & & & - & (Saricaoglu et al. 2014) \\
\hline S. canus & + & & & - & (Gupta et al. 2009) \\
\hline S. chromofuscus & - & & & - & (Gupta et al. 2009) \\
\hline S. exfoliatus & - & & & - & (Gupta et al. 2009) \\
\hline S. griseoluteus & - & & & - & (Gupta et al. 2009) \\
\hline S. hainanensis & - & & & - & (Saricaoglu et al. 2014) \\
\hline S. helstedii & + & & & + & (Gupta et al. 2009) \\
\hline S. hoynatensis & - & & & - & (Saricaoglu et al. 2014) \\
\hline S. karpasiensis & & & & + & (Veyisoglu et al. 2014) \\
\hline S. laculatispora & & & & + & (Zucchi et al. 2012) \\
\hline S. lavenduale & + & & & - & (Gupta et al. 2009) \\
\hline S. lomondensis & + & & & & (Santhanam et al. 2012) \\
\hline S. longisporoflavus & - & & & - & (Gupta et al. 2009) \\
\hline S. luridus & + & & & - & (Gupta et al. 2009) \\
\hline S. lusitanus & + & & & + & (Zucchi et al. 2012) \\
\hline
\end{tabular}


Table 2 (continued)

\begin{tabular}{|c|c|c|c|c|c|}
\hline Bacteria & Xanthine & Hypoxanthine & Uric acid & Allantoin & References \\
\hline S. lydicus & + & & & - & (Gupta et al. 2009) \\
\hline S. mayteni & - & & & - & (Saricaoglu et al. 2014) \\
\hline S. melanogenes & & & + & - & (Idris et al. 2017) \\
\hline S. noboritoensism & & & + & - & (Idris et al. 2017) \\
\hline S. nogalator & + & & & - & (Gupta et al. 2009) \\
\hline S. pactum & + & & & - & (Gupta et al. 2009) \\
\hline S. plumbiresistens & & & & + & (Tatar and Sahin 2015) \\
\hline S. polyantibioticus & & & - & + & (Idris et al. 2017) \\
\hline S. prasinosporus & - & & & - & (Gupta et al. 2009) \\
\hline S. pseudovenezuelae & & & & + & (Tatar and Sahin 2015) \\
\hline S. purpureus & + & & & - & (Gupta et al. 2009) \\
\hline S. samsunensis & - & + & & & (Nalubega et al. 2016) \\
\hline S. sedi & - & & & - & (Saricaoglu et al. 2014) \\
\hline S. seymenliensis & & & & + & (Tatar and Sahin 2015) \\
\hline S. specialis & - & & & - & (Saricaoglu et al. 2014) \\
\hline S. tubercidicus & + & & & - & (Gupta et al. 2009) \\
\hline S. varsoviensis & + & & & - & (Gupta et al. 2009) \\
\hline S. viridochromogenes & + & & & - & (Gupta et al. 2009) \\
\hline S. xanthochromogenes & + & & & - & (Gupta et al. 2009) \\
\hline Verrucosispora fiedleri & & & & + & (Xie et al. 2018) \\
\hline V. gifhornensis & & & & + & (Xie et al. 2018) \\
\hline V. maris & & & & + & (Xie et al. 2018) \\
\hline V. rhizosphaerae & & & & - & (Xie et al. 2018) \\
\hline
\end{tabular}

“+," catabolized; “-," not catabolized; empty cells indicate no reports found on the catabolism of the referred N compound; *also allantoate

\section{Scenario 1: xanthine and hypoxanthine}

As mentioned previously, most of the PAB studied thus far harbor the complete set of genes for the purine metabolism as well as $(i)$ the functional high-affinity transporters for adenine (PurP and $\mathrm{YicO}$ ) or hypoxanthine/guanine (YjcD and $\mathrm{YgfQ}$ ), belonging to cluster COG2252 of the evolutionarily broad family NCS2 in E. coli (Papakostas et al. 2013), (ii) the NAT/ NCS2 (nucleobase ascorbate transporters or nucleobase cation symporter family 2), (iii) the NCS1 (nucleobase cation symporter family 1) purine transporters (Ma et al. 2016), and (iv) the xanthine permease XanQ in E. coli K-12 (Frillingos 2012). Thus, proliferation of PAB with the ability to scavenge xanthine or hypoxanthine from the surrounding media could deplete the plant cells of these substrates for the enzymes XHD and XO. This situation may result in the plants exhibiting reduced rates of ureide synthesis or with lower effectiveness of the oxidative defense responses. Examples of bacterial species with or without the ability to use xanthine and hypoxanthine as an $\mathrm{N}$ source for growth are listed in Table 2. Concomitantly, the presence of high hypoxanthine producer bacteria, as it is the case of Lysinibacillus fusiformis (Gallegos-Monterrosa et al. 2016), could increase the bacterial XDH or XO activities (Self 2002). Moreover, in a nutrient-deprived environment, single S. aureus (ATCC 25923) and E. coli (ATCC 25922) bacterium can release $\sim 10^{6}$ purine derivative molecules mainly adenine, guanine, hypoxanthine, and xanthine per hour, pointing out changes in their purine salvage process in response to starvation (Chiu et al. 2018). The identification in Ps. putida KT2440 of chemoreceptors which specifically recognizes guanine, xanthine, 


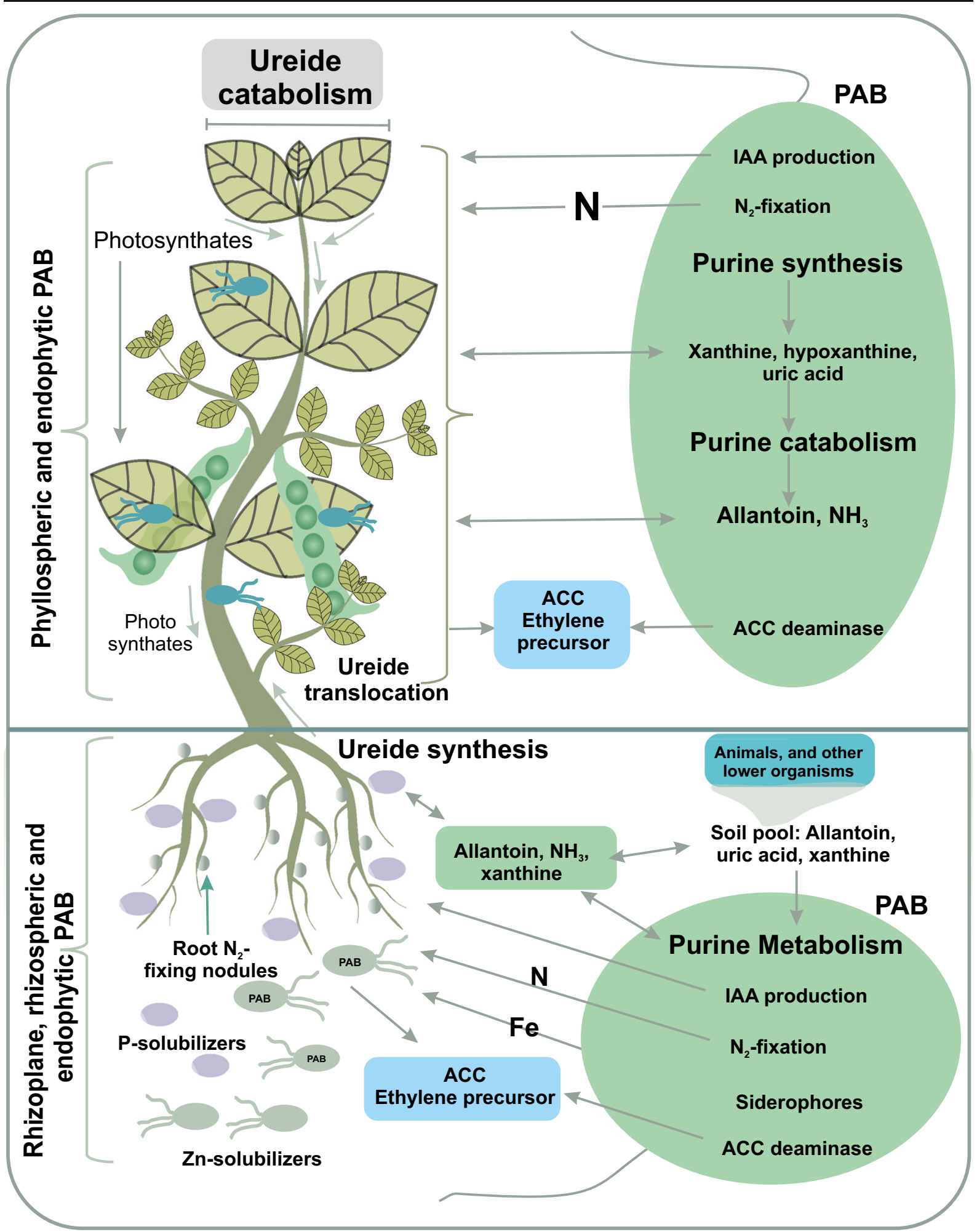

Fig. 2 Purine metabolism interactive scenarios between a plant and its plant-associated bacteria. Details of metabolic pathways and corresponding references are outlined in the text 
hypoxanthine, and uric acid could explain the high biodiversity and size of bacterial populations in ureideenriched rhizospheric soils and $\mathrm{N}_{2}$-fixing nodules in ureidic legumes (Fernández et al. 2016). A very interesting discovery is the capacity of bacteroids of Bradyrhizobium elkanii USDA76 to enzymatically reassimilate $5-16 \%$ of the $\mathrm{N}_{2}$ fixed by the nitrogenase through the purine pathway that includes five isoforms of XDH ending with the synthesis of uric acid, as uricase was not detected (Cooper et al. 2018). The same authors suggested that the recycling of purine intermediates is associated with a higher effectiveness of the symbiosis between $B$. elkanii USDA76 and soybean $\mathrm{cv}$. Peking.

\section{Scenario 2: ureides (allantoin and allantoate)}

Shorey (1947) was the first to recognize the relatively high content of allantoin in soils of diverse types and compositions in the USA. In soil, the allantoin pool is sustained by the decomposition of plant tissues, the excretion of ureide-enriched root exudates (Wang et al. 2007), and the ureides released from decaying or active $\mathrm{N}_{2}$-fixing nodules $\left(24.7 \mathrm{~g} \cdot \mathrm{N} \cdot \mathrm{L}^{-1} \cdot \mathrm{day}^{-1}\right.$ ) (Ofosu-Budu et al. 1995). Furthermore, the soil allantoin pool can be increased by daily animal urinary excretions containing up to $22.2 \%$ allantoin $\left(429 \mathrm{mmol}^{-1 a y}{ }^{-1}\right.$ ) (Wang et al. 2007; Nikkhah 2016; Yang et al. 2016), excreted by earthworms (Lumbricus terrestris) (Cohen and Lewis 1949), and/or by seasonal fires (Cobo-Díaz et al. 2015). Concomitantly, the soil uric acid, hypoxantine, and xanthine pools could also be significantly augmented via animal urinary excretions (Zhou et al. 2017). On the contrary, the soil allantoin pool can be depleted by $\mathrm{N}_{2^{-}}$ fixing filamentous cyanobacteria species found colonizing roots of a number of plant species (Prasad 1983; Gantar et al. 1991) and capable of using purine products for growth. Allantoin is also taken up by germinating spores of B. fasitidiosus (Salas and Eliar 1985) as well as by populations of soil bacteria and actinomycetes, and is known to stimulate the germination and growth of Echinochloa crus-galli (Wang et al. 2007). Examples of bacterial capable to hydrolyze allantoin are listed in Table 2.

Under stressful conditions, many PABs catabolize allantoin to release 4-M equivalents of $\mathrm{NH}_{3}$ at a low $\mathrm{C}$ / $\mathrm{N}$ cost. For example, the $22-\mathrm{kb}$ chromosomal all-gene locus responsible for ureide catabolism elevates the capability of $K$. pneumoniae to compete for allantoin as a pivotal $\mathrm{N}$ source for growth and replication (Chou et al. 2004; Li et al. 2014). Most methylobacteria do not fix $\mathrm{N}_{2}$ in the phyllosphere but carry genes for the complete sets of ureide catabolism (allantoinase, allantoate amidohydrolase, and ureidoglycorate urea-lyase) suggesting the possibility that PAB utilize urea and ureide generated by $\mathrm{N}_{2}$-fixing legumes as an $\mathrm{N}$ source (Minami et al. 2016). Under $\mathrm{N}$-limiting conditions, the capacity of B. cenocepacia strain H111 to use allantoin as N source depends on the functionality of the response regulator $\mathrm{NtrC}$ for $\mathrm{N}$ starvation (Liu et al. 2017b). In B. subtilis, allantoin from the growing media is transported into the cells by the putative 12-helix PucINCS-1 family of secondary active transporter encoded by the pucI gene (Ma et al. 2016). The NCS1 Mhp1 symport located in the cytoplasmic cell membrane promotes the uptake of allantoin into $M$. liquefaciens, serving as part of a salvage purine pathway (Patching 2017). These transporters allow bacteria to scavenge even small concentrations of soil allantoin. Interestingly, soil-occurring purines are toxic to microbial strains lacking allantoinase activity (Darlington and Scazzocchio 1967). On the other hand, the promoted growth of barnyardgrass by the allantoin released from roots of non-allelopathic rice cultivars in paddy soils (Sun et al. 2012) and the promotion of the jasmonic acid responsive genes in Arabidopsis thaliana supplied with allantoin $(100 \mathrm{mM})$ (Takagi et al. 2016) are indicators of the capacity of plants to uptake soil allantoin. The possibility exists that not all the soil allantoin enters the root and root nodules due to the capacity of soil microbiota to degrade allantoin to $\mathrm{NH}_{4}^{+}$, to be further taken up and assimilated (Imsande 1986).

For plants grown in low-N soils, a collateral benefit of an active ureide catabolism in PAB is the excessive production of intracellular $\mathrm{NH}_{4}{ }^{+}$and $\mathrm{NH}_{3}$ that must be excreted from the bacteria to the surrounding environment as it is the case of $S$. coelicolor fed with allantoin (20 mM) in a minimal N medium (Navone et al. 2014). Although, elevated levels of $\mathrm{NH}_{4}{ }^{+}$and $\mathrm{NH}_{3}$ might inhibit the transcription of $M s U 2$ gene in roots and nodules hindering the $\mathrm{N}_{2}$ fixation due to inhibition of the nodule UOX activity ( $\mathrm{Li}$ et al. 2015). In nature, this situation may be counteracted by the urease activity and uric acid transporter (pucJK) present in B. subtilis (Bongaerts and Vogels 1976; Ma et al. 2016), as well as by the degradation of urea and the incorporation of the $\mathrm{NH}_{3}$ into cell material as in Hydrogenomonas eutropha 
(Ammann and Reed 1967), K. pneumoniae (Li et al. 2014), and Rhodopseudomonas palustris (Naito et al. 2016). Evidences indicate the capacity of PAB and plants to incorporate the available $\mathrm{NH}_{3}$ into amino acids via the glutamine synthetase-glutamate synthase pathway (Tian et al. 2017; Zhang et al. 2017c).

\section{Scenario 3: $\mathbf{N}_{2}$-fixing ureidic legumes}

In $\mathrm{N}_{2}$-fixing ureidic legumes, the most relevant impact of soil allantoin can be the inhibition of $\mathrm{N}_{2}$ fixation as shown in rhizobia-nodulated soybean exogenously supplied with allantoin (5 mM) (Serraj et al. 1999) or allantoate (5-10 mM) (Serraj and Sinclair 2003). Furthermore, the uptake of allantoin $\left(5 \mathrm{mg} . \mathrm{L}^{-1}\right)$ by $24-\mathrm{h}$ soaked Phaseolus vulgaris seeds (Luis Cabrera-Ponce et al. 2015) raises the question of soil allantoin feedback inhibiting nodulation in legumes sown in soils containing elevated allantoin levels. Moreover, allantoin may enter roots and nodules via the UPS family of transporters for its utilization as $\mathrm{N}$ source (Lescano et al. 2016). The allantoin transport for endodermis crossing, root xylem loading, and subsequent export to the shoots is mediated by the GmUPS1 in soybean similar to the AtUPS5 (A. thaliana Ureide Permease 5) (Lescano et al. 2016). On the other hand, bacterial-excreted xanthine or hypoxanthine could also cause a feedback inhibition of the $\mathrm{N}_{2}$ fixation in root nodules, or may cause high $\mathrm{XO}$ activity rates resulting in toxic levels of ROS in plant cells that, in turn could block, for example, the colonization of root by effective rhizobia (Zipfel and Oldroyd 2017).

Examples of interactive association between plants and associated PAB on plant ureide metabolism are $(i)$ the increased relative ureide index (RUI) measured in the xylem sap of non-nodulated soybean varieties colonized by endophytic Streptomyces sp. strain P4, or in the rhizobia-nodulated soybean varieties Hinthada and SJ5 co-inoculated with Streptomyces sp. and B. japonicum strain USDA110, when compared to the lower RUI measured in the nodulated soybean varieties coinoculated with Streptomyces sp. and the B. japonicum strain THA7 (Soe et al. 2012) and (ii) the enhanced leaf ureide content in B. japonicum strain 14M2b-nodulated soybean co-inoculated with $A$. canadense strain DS2 (Juge et al. 2012). An interesting discovery was the absence of the genes for the ureidoglycorate urea-lyase that catalyze the last step of ureide degradation in Methylobacterium sp. strains 4-46 and WSM2598 nodulating Lotonosis bainesii, to avoid the deploy of nodule ureides for colony growth (Minami et al. 2016). Another relevant discovery is the plasticity of the purine catabolism in $M$. aquaticum, $M$. platan, and M. tarhaniae that do not catabolize allantoin in soils (Veyisoglu et al. 2013), but express all the genes for the complete sets of enzymes (allantoinase, allantoate amidohydrolase, and ureidoglycorate urea-lyase) for ureide degradation as soybean stem endophytes (Minami et al. 2016). Examples of bacteria capable to hydrolyze allantoin are listed in Table 2.

A myriad of reports has demonstrated the $\mathrm{N}$ enrichment of soils by $\mathrm{N}_{2}$-fixing legumes (Blesh 2018). Thus, it can be assumed that $\mathrm{N}$ released from active or senescence root $\mathrm{N}_{2}$-fixing nodules would be mainly in the form of ureide with a known direct impact on microbial species richness and diversity compared with soils with low ureide content (Wang et al. 2010). Despite the relevance of allantoin on soil microbiome, the description of the chemical constitution of the soil total $\mathrm{N}$ in terms of purine content is not included in the vast majority of publications. As shown by Wang et al. (2007), exogenous additions of 100 or $500 \mu \mathrm{g}$ allantoin per gram of soil increase by 3- or 5-fold the number of colony forming bacteria/gram soil, respectively. In the case of $\mathrm{N}_{2}$-fixing bacteria different from rhizobia, there are no evidences on ureides being synthesized in the colonized roots to be translocated via the xylem to sink organs. Very low ureide levels were detected in Paraburkholderia-root nodulated Mimosa spp. native to neotropical savannas (Izaguirre-Mayoral, unpublished data).

\section{Conclusions and final remarks}

Knowledge of the underlying physiological mechanisms by which PAB mediate stress tolerance is critical for the effective use of PAB to assure sustained agricultural production in changing environmental conditions. However, the co-selection of microbiota with an efficient purine metabolism according to the plant genome and prevailing abiotic stresses is not an easy task to achieve. For example, the popularization of the use of the lower-cost rock phosphate instead of triple superphosphate by farmers switches the dominance of Proteobacteria to that of Oxalobacteraceae (mainly Massilia and Herbaspirillum), augmenting the soil populations of Klebsiella, Burkholderia, and Bacillus species 
(Silva et al. 2017a). At the soil level, the composition of the microbiota thriving at the root-soil interface is largely determined by the soil $\mathrm{pH}$ (Bang-Andreasen et al. 2017; Zhang et al. 2017b), by the soil chemical composition (Canellas and Olivares 2017), and the prevailing agricultural management practices (Hartman et al. 2018). The behavior of the soil microbial communities seems also to be linked to the expression of the bacterial type VI secretion systems, quorum sensing, and biofilm formation (Gallique et al. 2017). At the plant level, rhizopheric and endophytic microbial populations undergo variations in size and biodiversity throughout the plant life cycle and are affected by the selective pressures exerted by crop domestication and plant physiological traits (Senga et al. 2017). Concomitantly, there are complex interactions between the size of the plant aerial mass and the size of the population of soil heterotrophic microorganisms involved in soil-plant $\mathrm{N}$ cycling leading to alteration in the ${ }^{15} \mathrm{~N}$ values in plant tissues (Jiang et al. 2017). On the other hand, plant genetic traits in terms of cell sensors and receptors to bacteria seem to be the final molecular factors controlling the biodiversity of taxa associated microbiota ( $\operatorname{Ranf} 2017)$. An example is the reported degree on the specificity of particular bacterial genotypes for particular sugarcane cultivars, depending on geographic origin and level of fertilizers used (Kruasuwan and Thamchaipenet 2016).

The complexity of plant-associated microbiome was recently emphasized by the aerial long-distance transport of microbes from terrestrial habitats and plant surfaces to be ground far away by seasonal rains (Hiraoka et al. 2017). The analysis is further complicated by the great variability among bacterial strains within a determinate genus in terms of $\mathrm{N}$ metabolism, $\mathrm{N}_{2}$-fixation, IAA production and the ACCD activity (Supplementary Tables 1-6), and pivotal bacterial traits to help plants to survive in abiotically stressed conditions. A breakthrough in breeding for salinity tolerance is the generation of salt-tolerant transgenic Camelina sativa expressing the Ps. putida UW4 acdS gene encoding the ACCD under the control of the root-specific promoter (rolD) (Heydarian et al. 2016). It is interesting to speculate that the evolutionary drive for microbes to establish association with plants was to have access to the nutrient resources that plants provide and to maximize this new nutritional niche. Furthermore, there is an estimate of 69,365 genes involved in a wide range of bacterial biological metabolic processes and responses to environmental conditions that are prone to undergo horizontal transfer (Jeong and Nasir 2017). There is also a new set of multiple functions described for the extracellular soil DNA of microbial origin, the most import being the ensurement of the intraspecific genetic flow, guaranteeing the adaptation and survival of the species and the construction of multicellular communities (Ibáñez de Aldecoa et al. 2017). The communication between plants and soil microbial community represents a bilateral process that goes beyond root exudates and microbial-elaborated signal response molecules.

Given widespread concerns for crop losses due to the drastically changing climate, the understanding of the interactive signaling for the purine metabolisms among $\mathrm{PAB}$ as well as between PAB consortia and plants takes on importance, as it may support management decisions necessary to maintain PAB biodiversity and the pivotal roles of agricultural services provided by bacterial consortium to crops. The recent discovery of the $B$. megaterium inducing the expression of the guanine nucleotide-binding protein beta subunit in roots of the ethylene-insensitive tomato never ripe (Ibort et al. 2018) further confirms the benefits of PAB on stresschallenged plants. The overexpression of this Gprotein $\beta$-subunit in transgenic Nicotiana tabacum significantly enhanced the plants' drought tolerance (Liu et al. 2017a). A community-level view that considers multiple PAB species interactions provides the best approach to this topic. Available technologies such as the high-resolution tridimensional images of leaf surfaces using taxon-specific fluorescently labeled oligonucleotide probes (Peredo and Simmons 2018) and metagenomic information (Kimura 2018) could help to identify bacterial trait-based mechanisms. An alert on the flaws inherent to the compositional nature of the datasets derived from microbiome studied by highthroughput sequencing (HTS) of 16S rRNA gene amplimers, metagenomes, or metatranscriptomes was issued by Gloor et al. (2017).

To date, however, quantitative metabolic models that can serve as a starting point for generating experimentally testable hypotheses for interactive exchanges of purine derivatives between associated microbiome and plants are not available. Based on the information compiled for this review, it is evident that $(i)$ the way microbes manipulate plant purine intermediates at biotrophic interfaces and finally control the outcome of ureides is still unclear and (ii) the categorization of PAB as growth promoters could not be based exclusively on the bacterial cultural properties, synthesis of 
phytohormones, and ACCD activity, as at present. Studies on the functionality of PAB must include the denitrification, cellulolytic, hemicellulolytic, and purine scavenger abilities of bacterial isolates, as well as the interactive plant-bacteria purine exchanges under abiotic challenging conditions.

Acknowledgments The authors express their appreciation to Dr. H. Allen Jr. (USDA, Florida) and to the two referees who remain anonymous for their editorial help and for providing enlightening comments that greatly improved this manuscript.

\section{References}

Aaronsoni S (1955) The purine requirement of Staphylococcus flavocyaneus. J Gen Microbiol 12:147-155. https://doi. org/10.1099/00221287-12-1-147

Aeron A, Chauhan PS, Dubey RC, Maheshwari DK, Bajpai VK (2015) Root nodule bacteria from Clitoria ternatea L. are putative invasive nonrhizobial endophytes. Can J Microbiol 142:131-142. https://doi.org/10.1139/cjm-2014-0483

Aguilar A, Peralta H, Mora Y, Díaz R, Vargas-Lagunas C, Girard L, Mora J (2016) Genomic comparison of Agrobacterium pusense strains isolated from bean nodules. Front Microbiol 7:1720. https://doi.org/10.3389/fmicb.2016.01720

Al-Dilaimi A, Bednarz H, Lomker A, Niehaus K, Kalinowski J, Ruckert C (2015) Revisiting Corynebacterium glyciniphilum (ex Kubota et al., 1972) sp. nov., nom. rev., isolated from putrefied banana. Int J Syst Evol Microbiol 65:177-182. https://doi.org/10.1099/ijs.0.065102-0

Ali N, Al-Awadhi H, Dashti N, Khanafer M, El-Nemr I, Sorkhoh N, Radwan SS (2015) Bioremediation of atmospheric hydrocarbons via bacteria naturally associated with leaves of higher plants. Int J Phytoremediat 17:1160-1170. https://doi.org/10.1080/15226514.2015.1045125

Aly M, Tork S, Al-Garni S, Allam R (2013) Production and characterization of uricase from Streptomyces exfoliatus UR10 isolated from farm wastes. Turk J Biol 37:520-529. https://doi.org/10.3906/biy-1206-3

Amirthanathan A, Vijayakumar S (2011) Purification and optimization of uricase enzyme produced by Pseudomonas aeruginosa. Exp Sci 2:5-8

Ammann ECB, Reed LL (1967) Metabolism of nitrogen compounds by Hydrogenomonas eutropha. Biochim Biophys Acta 141:135-143. https://doi.org/10.1016/0304-4165(67 )90252-8

Annapurna K, Ramadoss D, Bose P, VithalKumar L (2013) In situ localization of Paenibacillus polymyxa HKA-15 in roots and root nodules of soybean (Glycine max L.). Plant Soil 373: 641-648. https://doi.org/10.1007/s11104-013-1825-7

Ardley JK, Parker MA, De Meyer SE, Trengove RD, O'Hara GW, Reeve WG, Yates RJ, Dilworth MJ, Willems A, Howieson JG (2012) Microvirga lupini sp. nov., Microvirga lotononidis sp. nov. and Microvirga zambiensis sp. nov. are alphaproteobacterial root-nodule bacteria that specifically nodulate and fix nitrogen with geographically and taxonomically separate legume hosts. Int J Syst Evol Microbiol 62:2579-2588. https://doi.org/10.1099 /ijs.0.035097-0

Arone G, Calderón C, Moreno S, Bedmar EJ (2014) Identification of Ensifer strains isolated from root nodules of Medicago hispida grown in association with Zea mays in the Quechua region of the Peruvian Andes. Biol Fertil Soils 50:185-190. https://doi.org/10.1007/s00374-013-0825-3

Aydogan EL, Busse H-J, Moser G, Müller C, Kämpfer P, Glaeser SP (2016) Aureimonas galii sp. nov. and Aureimonas pseudogalii sp. nov. isolated from the phyllosphere of Galium album. Int J Syst Evol Microbiol 66:3345-3354. https://doi.org/10.1099/ijsem.0.001200

Azab EA, Ali MM, Fareed MF (2005) Studies on uricase induction in certain bacteria. Egypt J Biol 7:44-54

Bai Y, Aoust FD, Smith DL, Driscoll BT (2002) Isolation of plantgrowth-promoting Bacillus strains from soybean root nodules. Can J Microbiol 48:230-238. https://doi.org/10.1139 /W02-014

Bang-Andreasen T, Nielsen JT, Voriskova J, Heise J, Rønn R, Kjøller R, Hansen HCB, Jacobsen CS (2017) Wood ash induced $\mathrm{pH}$ changes strongly affect soil bacterial numbers and community composition. Front Microbiol 8:1400. https://doi.org/10.3389/fmicb.2017.01400

Baral B, Izaguirre-Mayoral ML (2017) Purine-derived ureides under drought and salinity. In: Sparks DL (ed) Advances in agronomy. Academic Press, pp 167-204

Baral B, Teixeira da Silva JA, Izaguirre-Mayoral ML (2016) Early signaling, synthesis, transport and metabolism of ureides. J Plant Physiol 193:97-109. https://doi.org/10.1016/j. jplph.2016.01.013

Batista BD, Lacava PT, Ferrari A, Teixeira-Silva NS, Bonatelli ML, Tsui S, Mondin M, Kitajima EW, Pereira JO, Azevedo JL, Quecine MC (2018) Screening of tropically derived, multi-trait plant growth-promoting rhizobacteria and evaluation of corn and soybean colonization ability. Microbiol Res 206:33-42. https://doi.org/10.1016/j.micres.2017.09.007

Bautista VV, Monsalud RG, Yokota A (2010) Devosia yakushimensis sp. nov., isolated from root nodules of Pueraria lobata (Willd.) Ohwi. Int J Syst Evol Microbiol 60:627-632. https://doi.org/10.1099/ijs.0.011254-0

Bautista VV, Monsalud RG, Yokota A (2017) Identification of bacteria from root nodules of Philippine legumes using 16S rRNA gene sequencing. Philipp Agric Sci 100:415-428

Beghalem H, Aliliche K, Chriki A, Landoulsi A (2017) Molecular and phenotypic characterization of endophytic bacteria isolated from sulla nodules. Microb Pathog 111:225-231. https://doi.org/10.1016/j.micpath.2017.08.049

Blesh J (2018) Functional traits in cover crop mixtures: biological nitrogen fixation and multifunctionality. J Appl Ecol 55:3848. https://doi.org/10.1111/1365-2664.13011

Bojanowski R, Gaudy E, Valentine RC, Wolfe RS (1964) Oxamic transcarbamylase of Streptococcus allantoicus. J Bacteriol $87: 75-80$

Bongaerts GPA, Vogels GD (1976) Uric acid degradation by Bacillus fastidiosus strains. J Bacteriol 125:689-697

Boonsnongcheep P, Prathanturarug S, Takahashi Y, Matsumoto A (2016) Rhizobium puerariae sp. nov., an endophytic bacterium from the root nodules of the medicinal plant Pueraria candollei var. candollei. Int J Syst Evol Microbiol 66:12361241. https://doi.org/10.1099/ijsem.0.000863 
Bouchiba Z, Boukhatem ZF, Zo I, Derkaoui N, Kerdouh B, Abdelmoumen H, Abbas Y, El Idrissi MM, Bekki A (2017) Diversity of nodular bacteria of Scorpiurus muricatus in Western Algeria and their impact on plant growth. Can J Microbiol 63:450-463. https://doi.org/10.2135 /cropsci2015.09.0557

Bounaffaa M, Florio A, Le Roux X, Jayet P-A (2018) Economic and environmental analysis of maize inoculation by plant growth promoting rhizobacteria in the French Rhône-Alpes region. Ecol Econ 146:334-346. https://doi.org/10.1016/j. ecolecon.2017.11.009

Busarakam K, Brown R, Bull AT, Tan GYA, Zucchi TD, da Silva LJ, de Souza WR, Goodfellow M (2016) Classification of thermophilic actinobacteria isolated from arid desert soils, including the description of Amycolatopsis deserti sp. nov. Antonie van Leeuwenhoek. Int J Gen Mol Microbiol 109: 319-334. https://doi.org/10.1007/s10482-015-0635-8

Camas M, Veyisoglu A, Sahin N (2017) Nocardia sungurluensis sp. nov., isolated from soil. Int J Syst Evol Microbiol 64: 1629-1634. https://doi.org/10.1099/ijs.0.051334-0

Canellas LP, Olivares FL (2017) Production of border cells and colonization of maize root tips by Herbaspirillum seropedicae are modulated by humic acid. Plant Soil 417: 403-413. https://doi.org/10.1007/s11104-017-3267-0

Cantu-Medellin N, Kelley EE (2013) Xanthine oxidoreductasecatalyzed reduction of nitrite to nitric oxide: insights regarding where, when and how. Nitric Oxide 34:19-26. https://doi. org/10.1016/j.niox.2013.02.081

Carro L, Flores-Félix JD, Cerda-Castillo E, Ramírez-Bahena MH, Igual JM, Tejedor C, Velázquez E, Peix A (2013) Paenibacillus endophyticus sp. nov., isolated from nodules of Cicer arietinum. Int J Syst Evol Microbiol 63:4433-4438. https://doi.org/10.1099/ijs.0.050310-0

Carro L, Flores-Félix JD, Ramírez-Bahena MH, García-Fraile P, Martínez-Hidalgo P, Igual JM, Tejedor C, Peix A, Velázquez E (2014) Paenibacillus lupini sp. nov., isolated from nodules of Lupinus albus. Int J Syst Evol Microbiol 64:3028-3033. https://doi.org/10.1099/ijs.0.060830-0

Carro L, Veyisoglu A, Riesco R, Spröer C, Klenk H-P, Sahin N, Trujillo ME (2017) Micromonospora phytophila sp. nov. and Micromonospora luteiviridis sp. nov., isolated as natural inhabitants of plant nodules. Int J Syst Evol Microbiol. https://doi.org/10.1099/ijsem.0.002490

Castellano-Hinojosa A, Correa-Galeote D, Palau J, Bedmar EJ (2016) Isolation of N2-fixing rhizobacteria from Lolium perenne and evaluating their plant growth promoting traits. J Basic Microbiol 56:85-91. https://doi.org/10.1002 /jobm.201500247

Cendron L, Ramazzina I, Puggioni V, Maccacaro E, Liuzzi A, Secchi A, Zanotti G, Percudani R (2016) The structure and function of a microbial allantoin racemase reveal the origin and conservation of a catalytic mechanism. Biochemistry 55: 6421-6432. https://doi.org/10.1021/acs.biochem.6b00881

Chagas FO, Pessotti RC, Caraballo-Rodríguez AM, Pupo MT (2018) Chemical signaling involved in plant-microbe interactions. Chem Soc Rev. https://doi.org/10.1039/C7CS00343 A

Chaïch K, Bekki A, Bouras N, Holtz MD, Soussou S, Mauré L, Brunel B, de Lajudie P, Cleyet-Marel JC (2017) Rhizobial diversity associated with the spontaneous legume Genista saharae in the northeastern Algerian Sahara. Symbiosis 71: 111-120. https://doi.org/10.1007/s13199-016-0414-y

Chase AB, Arevalo P, Polz MF, Berlemont R, Martiny JBH (2016) Evidence for ecological flexibility in the cosmopolitan genus Curtobacterium. Front Microbiol 7:1874. https://doi. org/10.3389/fmicb.2016.01874

Checcucci A, Azzarello E, Bazzicalupo M, De Carlo A, Emiliani G, Mancuso S, Spini G, Viti C, Mengoni A (2017) Role and regulation of ACC deaminase gene in Sinorhizobium meliloti: is it a symbiotic, rhizospheric or endophytic gene? Front Genet 8:6. https://doi.org/10.3389/fgene.2017.00006

Chinnaswamy A, Coba de la Peña T, Stoll A, de la Peña Rojo D, Bravo J, Rincón A, Lucas MM, Pueyo JJ (2018) A nodule endophytic Bacillus megaterium strain isolated from Medicago polymorpha enhances growth, promotes nodulation by Ensifer medicae and alleviates salt stress in alfalfa plants. Ann Appl Biol:1-14. https://doi.org/10.1111 /AAB. 12420

Chiu SW-Y, Cheng H-W, Chen Z-X, Wang H-H, Lai M-Y, Wang J-K, Wang Y (2018) Quantification of biomolecules responsible for the biomarkers in the surface-enhanced raman spectra of bacteria using liquid chromatography-mass spectrometry. Phys Chem Chem Phys. https://doi.org/10.1039/C7 CP07103E

Chou H, Lee C, Ma L, Fang C, Chang S, Wang J (2004) Isolation of a chromosomal region of Klebsiella pneumoniae associated with allantoin metabolism and liver infection. Infect Immun 72:3783-3792. https://doi.org/10.1128 /IAI.72.7.3783

Cobo-Díaz J, Fernández-González A, Villadas P (2015) Metagenomic assessment of the potential microbial nitrogen pathways in the rhizosphere of a mediterranean forest after a wildfire. Microb Ecol 69:895-904. https://doi.org/10.1007 /s00248-015-0586-7

Cohen S, Lewis H (1949) The nitrogenous metabolism of the earthworm (Lumbricus terrestris). J Biol Chem 180:79-91

Cooper B, Campbell KB, Beard HS, Garrett WM, Mowery J, Bauchan GR, Elia P (2018) A proteomic network for symbiotic nitrogen fixation efficiency in Bradyrhizobium elkanii. Mol Plant-Microbe Interact 31:334-343. https://doi. org/10.1094/MPMI-10-17-0243-R

Cronan CS (2018) Microbial biogeochemistry. Ecosyst Biogeochem 6:31-40. https://doi.org/10.1016/0009-2541 (70)90033-1

Cunliffe M (2016) Purine catabolic pathway revealed by transcriptomics in the model marine bacterium Ruegeria pomeroyi DSS-3. FEMS Microbiol Ecol 92:1-6. https://doi. org/10.1093/femsec/fiv150

Danchin A (2017) Coping with inevitable accidents in metabolism. Microb Biotechnol 10:57-72. https://doi.org/10.1111 /1751-7915.12461

Darlington AJ, Scazzocchio C (1967) Use of analogues and the substrate-sensitivity of mutants in analysis of purine uptake and breakdown in Aspergillus nidulans. J Bacteriol 93:937940

De La Riva L, Badia J, Aguilar J, Bender RA, Baldoma L (2008) The hpx genetic system for hypoxanthine assimilation as a nitrogen source in Klebsiella pneumoniae: gene organization and transcriptional regulation. J Bacteriol 190:7892-7903. https://doi.org/10.1128/JB.01022-08 
de Matos GF, Zilli JE, de Araújo JLS, Parma MM, Melo IS, Radl V, Baldani JI, Rouws LFM (2017) Bradyrhizobium sacchari sp. nov., a legume nodulating bacterium isolated from sugarcane roots. Arch Microbiol:1-8. https://doi.org/10.1007 /s00203-017-1398-6

de Meyer SE, Tan HW, Andrews M, Heenan PB, Willems A (2016) Mesorhizobium calcicola sp. nov., Mesorhizobium waitakense sp. nov., Mesorhizobium sophorae sp. nov., Mesorhizobium newzealandense sp. nov. and Mesorhizobium kowhaii sp. nov. isolated from sophora root nodules. Int J Syst Evol Microbiol 66:786-795. https://doi. org/10.1099/ijsem.0.000796

Defez R, Andreozzi A, Bianco C (2017) The overproduction of indole-3-acetic acid (IAA) in endophytes upregulates nitrogen fixation in both bacterial cultures and inoculated rice plants. Microb Ecol 74:441-452. https://doi.org/10.1007 /s00248-017-0948-4

Del Arco J, Martinez M, Donday M, Clemente-Suarez VJ, Fernandez-Lucas J (2017) Cloning, expression and biochemical characterization of xanthine and adenine phosphoribosyltransferases from Thermus thermophilus HB8. Biocatal Biotransformat:1-8. https://doi.org/10.1080 /10242422.2017.1313837

Deng ZS, Zhao LF, Kong ZY, Yang WQ, Lindström K, Wang ET, Wei GH (2011) Diversity of endophytic bacteria within nodules of the Sphaerophysa salsula in different regions of Loess Plateau in China. FEMS Microbiol Ecol 76:463-475. https://doi.org/10.1111/j.1574-6941.2011.01063.x

Do Nascimento VC, Prete CEC, Nogueira MA (2016) Biological nitrogen fixation in soybean under water restriction and exposed to 1-methylcyclopropene. Pesq Agrop Brasileira 51:818-823. https://doi.org/10.1590/S0100-204 X2016000700004

Doniselli N, Monzeglio E, Dal Palù A, Merli A, Percudani R (2015) The identification of an integral membrane, cytochrome $\mathrm{c}$ urate oxidase completes the catalytic repertoire of a therapeutic enzyme. Sci Rep 5:13798. https://doi. org/10.1038/srep 13798

Duangmal K, Suksaard P, Pathom-Aree W, Mingma R, Matsumoto A, Takahashi Y (2016) Actinopolyspora salinaria sp. nov., a halophilic actinomycete isolated from solar saltern soil. Int J Syst Evol Microbiol 66:1660-1665. https://doi.org/10.1099/ijsem.0.000926

Durre P, Andersch W, Andreesen JR (1981) Isolation and characterization of an adenine-utilizing, anaerobic sporeformer, Clostridium purinolyticum sp. nov. Int J Syst Bacteriol 31: 184-194. https://doi.org/10.1099/00207713-31-2-184

Elliott GN, Chen W-M, Chou J-H, Wang H-C, Sheu S-Y, Perin L, Reis VM, Moulin L, Simon MF, Bontemps C, Sutherland JM, Bessi R, De Faria SM, Trinick MJ, Prescott AR, Sprent JI, James EK (2007) Burkholderia phymatum is a highly effective nitrogen-fixing symbiont of Mimosa spp. and fixes nitrogen ex planta. New Phytol 173:168-180. https://doi. org/10.1111/j.1469-8137.2006.01894.x

Emmyrafedziawati AKR, Stella M (2018) Identification of freeliving nitrogen fixing bacteria isolated from EFB compost, molecular detection of nifH gene and measurement of the nitrogenase activity. J Trop Agric Food Sci 46:39-46

Etesami H (2018) Can interaction between silicon and plant growth promoting rhizobacteria benefit in alleviating abiotic and biotic stresses in crop plants? Agric Ecosyst Environ 253: 98-112

Fernández M, Morel B, Corral-Lugo A, Krell T (2016) Identification of a chemoreceptor that specifically mediates chemotaxis toward metabolizable purine derivatives. Mol Microbiol 99:34-42. https://doi.org/10.1111/mmi.13215

Fitzpatrick CR, Copeland J, Wang PW, Guttman DS, Kotanen PM, Johnson MTJ (2018) Assembly and ecological function of the root microbiome across angiosperm plant species. Proc Natl Acad Sci. https://doi.org/10.1073/pnas.1717617115

Flores-Felix JD, Carro L, Ramirez-Bahena MH, Tejedor C, Igual JM, Peix A, Velazquez E (2014) Cohnella lupini sp. nov., an endophytic bacterium isolated from root nodules of Lupinus albus. Int J Syst Evol Microbiol 64:83-87. https://doi. org/10.1099/ijs.0.050849-0

French JB, Ealick SE (2010) Biochemical and structural characterization of a ureidoglycine aminotransferase in the Klebsiella pneumoniae uric acid catabolic pathway. Biochemistry 49:5975-5977. https://doi.org/10.1021 /bi1006755

Frillingos S (2012) Insights to the evolution of nucleobaseascorbate transporters (NAT/NCS2 family) from the Cysscanning analysis of xanthine permease XanQ. Int J Biochem Mol Biol 3:250-272

Gallegos-Monterrosa R, Maróti G, Bálint B, Kovács ÁT (2016) Draft genome sequence of the soil isolate Lysinibacillus fusiformis M5, a potential hypoxanthine producer. Genome Announc 4:e01272-e01216. https://doi.org/10.1128 /genomeA.01272-16

Gallique M, Bouteiller M, Merieau A (2017) The type VI secretion system: a dynamic system for bacterial communication? Front Microbiol 8:1454. https://doi.org/10.3389 /fmicb.2017.01454

Gantar M, Kerby NW, Rowell P, Obreht Z (1991) Colonization of wheat (Triticum vulgare L.) by $\mathrm{N}_{2}$-fixing cyanobacteria: I. A survey of soil cyanobacterial isolates forming associations with roots. New Phytol 118:477-483. https://doi.org/10.1111 jj.1469-8137.1991.tb00030.x

Gao D, Wang X, Fu S, Zhao J (2017) Legume plants enhance the resistance of soil to ecosystem disturbance. Front Plant Sci 8: 1295. https://doi.org/10.3389/fpls.2017.01295

Ghosh S, Ayayee PA, Valverde-Barrantes OJ, Blackwood CB, Royer TV, Leff LG (2017) Initial nitrogen enrichment conditions determines variations in nitrogen substrate utilization by heterotrophic bacterial isolates. BMC Microbiol 17:87. https://doi.org/10.1186/s12866-017-0993-7

Gloor GB, Macklaim JM, Pawlowsky-Glahn V, Egozcue JJ (2017) Microbiome datasets are compositional: and this is not optional. Front Microbiol 8:2224. https://doi.org/10.3389 /fmicb.2017.02224

Golinska P, Ahmed L, Wang D, Goodfellow M (2013) Streptacidiphilus durhamensis sp. nov., isolated from a spruce forest soil. Antonie Van Leeuwenhoek 104:199-206. https://doi.org/10.1007/s10482-013-9938-9

Gong S, Wang Y, Wang Z, Sun Y, Zhang W (2018) Folding behaviors of purine riboswitch aptamers. Wuhan Univ $\mathrm{J}$ Nat Sci 23:43-50. https://doi.org/10.1007/s11859-0181292-3

Gontia-Mishra I, Sapre S, Kachare S, Tiwari S (2017) Molecular diversity of 1-aminocyclopropane-1-carboxylate (ACC) deaminase producing PGPR from wheat (Triticum aestivum L.) 
rhizosphere. Plant Soil 414:213-227. https://doi.org/10.1007 /s11104-016-3119-3

Grönemeyer JL, Hurek T, Bünger W, Reinhold-Hurek B (2016) Bradyrhizobium vignae sp. nov., a nitrogen-fixing symbiont isolated from effective nodules of Vigna and Arachis. Int J Syst Evol Microbiol 66:62-69. https://doi.org/10.1099 /ijsem.0.000674

Gu Q, Pasciak M, Luo H, Gamian A, Liu Z, Huang Y (2007) Ruania albidiflava gen. nov., sp. nov., a novel member of the suborder Micrococcineae. Int J Syst Evol Microbiol 57:809814. https://doi.org/10.1099/ijs.0.64635-0

Gu CT, Wang ET, Tian CF, Han TX, Chen WF, Sui XH, Chen WX (2008) Rhizobium miluonense sp. nov., a symbiotic bacterium isolated from Lespedeza root nodules. Int J Syst Evol Microbiol 58:1364-1368. https://doi.org/10.1099 /ijs.0.65661-0

Gupta N, Mishra S, Basak U (2009) Diversity of Streptomyces in mangrove ecosystem of Bhitarkanika. Iran J Microbiol 1:3742

Guzmán K, Campos E, Aguilera L, Toloza L, Giménez R, Aguilar J, Baldoma L, Badia J (2013) Characterization of the gene cluster involved in allantoate catabolism and its transcriptional regulation by the RpiR-type repressor HpxU in Klebsiella pneumoniae. Int Microbiol 16:165-176. https://doi. org/10.2436/20.1501.01.191

Hafez RM, Abdel-Rahman TM, Naguib RM (2017) A review on uric acid in plants and microorganisms: biological applications and genetics. J Adv Res 8:475-486. https://doi. org/10.1016/j.jare.2017.05.003

Hajnal-Jafari T, Đurić S, Stamenov D (2018) Plant growth and yield enhancement of soybean by inoculation with symbiotic and nonsymbiotic bacteria. Int J Agric Biosyst Eng 12. https://doi.org/10.1999/1307-6892/80297

Harsha Shelat AD, Panpatte D (2017) Chryseobacterium indologene: a novel root nodule endophyte in Vigna radiata. Int J Curr Microbiol Appl Sci 6:836-844. https://doi. org/10.20546/ijcmas.2017.604.104

Hartman K, van der Heijden MGA, Wittwer RA, Banerjee S, Walser J-C, Schlaeppi K (2018) Cropping practices manipulate abundance patterns of root and soil microbiome members paving the way to smart farming. Microbiome 6:14. https://doi.org/10.1186/s40168-017-0389-9

Hasegawa A, Ogasawara H, Kori A, Teramoto J, Ishihama A (2008) The transcription regulator AIIR senses both allantoin and glyoxylate and controls a set of genes for degradation and reutilization of purines. Microbiology 154:3366-3378. https://doi.org/10.1099/mic.0.2008/020016-0

Hemkemeyer M, Dohrmann AB, Christensen BT, Tebbe CC (2018) Bacterial preferences for specific soil particle size fractions revealed by community analyses. Front Microbiol 9:1-13. https://doi.org/10.3389/fmicb.2018.00149

Heydarian Z, Yu M, Gruber M, Glick BR, Zhou R, Hegedus DD (2016) Inoculation of soil with plant growth promoting bacteria producing 1-aminocyclopropane-1-carboxylate deaminase or expression of the corresponding acdS gene in transgenic plants increases salinity tolerance in Camelina sativa. Front Microbiol 7:1966. https://doi.org/10.3389 /fmicb.2016.01966

Hicks KA, Ealick SE (2016) Biochemical and structural characterization of Klebsiella pneumoniae oxamate amidohydrolase in the uric acid degradation pathway. Acta Crystallogr Sect D
Struct Biol 72:808-816. https://doi.org/10.1107 /S2059798316007099

Hicks KA, O’Leary SE, Begley TP, Ealick SE (2013) Structural and mechanistic studies of $\mathrm{HpxO}$, a novel flavin adenine dinucleotide-dependent urate oxidase from Klebsiella pneumoniae. Biochemistry 52:477-487. https://doi. org/10.1021/bi301262p

Hiraoka S, Miyahara M, Fujii K, Machiyama A, Iwasaki W (2017) Seasonal analysis of microbial communities in precipitation in the Greater Tokyo Area, Japan. Front Microbiol 8:1506. https://doi.org/10.3389/fmicb.2017.01506

Hoque MS, Broadhurst LM, Thrall PH (2011) Genetic characterization of root-nodule bacteria associated with Acacia salicina and A. stenophylla (Mimosaceae) across southeastern Australia. Int J Syst Evol Microbiol 61:299-309. https://doi.org/10.1099/ijs.0.021014-0

Hossain MZ, Lundquist P-O (2016) Nodule inhabiting nonrhizobial bacteria and their influence on growth of selected leguminous plants of Bangladesh. Biores Commun 2:139145

Htwe AZ, Moh SM, Moe K, Yamakawa T (2018) Effects of coinoculation of Bradyrhizobium japonicum SAY3-7 and Streptomyces griseoflavus $\mathrm{P} 4$ on plant growth, nodulation, nitrogen fixation, nutrient uptake, and yield of soybean in a field condition. Soil Sci Plant Nutr:1-8. https://doi. org/10.1080/00380768.2017.1421436

Hung PQ, Annapurna K (2004) Isolation and characterization of endophytic bacteria in soybean (Glycine sp.). Omonrice 101: 92-101

Ibáñez de Aldecoa AL, Zafra O, González-Pastor JE (2017) Mechanisms and regulation of extracellular DNA release and its biological roles in microbial communities. Front Microbiol 8:1390. https://doi.org/10.3389/fmicb.2017.01390

Ibekwe AM, Gonzalez-Rubio A, Suarez DL (2017) Impact of treated wastewater for irrigation on soil microbial communities. Sci Total Environ. https://doi.org/10.1016/j. scitotenv.2017.10.039

Ibort P, Imai H, Uemura M, Aroca R (2018) Proteomic analysis reveals that tomato interaction with plant growth promoting bacteria is highly determined by ethylene perception. J Plant Physiol 220:43-59. https://doi.org/10.1016/j. jplph.2017.10.008

Idris H, Labeda DP, Nouioui I, Castro JF, del Carmen MonteroCalasanz M, Bull AT, Asenjo JA, Goodfellow M (2017) Streptomyces aridus sp. nov., isolated from a high altitude Atacama Desert soil and emended description of Streptomyces noboritoensis Isono et al. 1957. Antonie van Leeuwenhoek 110:705-717. https://doi.org/10.1007/s10482017-0838-2

Imsande J (1986) Degradation and utilization of exogenous allantoin by intact soybean root. Physiol Plant 68:685-688. https://doi.org/10.1111/j.1399-3054.1986.tb03418.x

Jeong H, Nasir A (2017) A preliminary list of horizontally transferred genes in prokaryotes determined by tree reconstruction and reconciliation. Front Genet 8:1-8. https://doi. org/10.3389/fgene.2017.00112

Jiang L, Wang S, Zhe P, Wang C, Kardol P, Zhong L, Yu Q, Lan Z, Wang Y, Xu X, Kuzyakov Y, Luo C, Zhang Z, Jones DL (2017) Effects of grazing on the acquisition of nitrogen by plants and microorganisms in an alpine grassland on the 
Tibetan plateau. Plant Soil 416:297-308. https://doi. org/10.1007/s11104-017-3205-1

Jourand P, Giraud E, Béna G, Sy A, Willems A, Gillis M, Dreyfus B, de Lajudie P (2004) Methylobacterium nodulans sp. nov., for a group of aerobic, facultatively methylotrophic, legume root-nodule-forming and nitrogen-fixing bacteria. Int J Syst Evol Microbiol 54:2269-2273. https://doi.org/10.1099 /ijs.0.02902-0

Juge C, Prévost D, Bertrand A, Bipfubusa M, Chalifour FP (2012) Growth and biochemical responses of soybean to double and triple microbial associations with Bradyrhizobium, Azospirillum and arbuscular mycorrhizae. Appl Soil Ecol 61:147-157. https://doi.org/10.1016/j.apsoil.2012.05.006

Kämpfer P, Glaeser SP, Kloepper JW, Hu C-H, McInroy JA, Martin K, Busse H-J (2016) Isoptericola cucumis sp. nov., isolated from the root tissue of cucumber (Cucumis sativus). Int J Syst Evol Microbiol 66:2784-2788. https://doi. org/10.1099/ijsem.0.001055

Kang S-J, Jung Y-T, Oh K-H, Oh T-K, Yoon J-H (2011) Mucilaginibacter boryungensis sp. nov., isolated from soil. Int J Syst Evol Microbiol 61:1549-1553. https://doi. org/10.1099/ijs.0.024950-0

Khade S, Srivastava SK (2016) Effect of surfactants and inducers on increased uricase production under submerged fermentations (SMF) by Bacillus cereus. Prep Biochem Biotechnol 47:81-85. https://doi.org/10.1080/10826068.2016.1168842

Khalifa AYZ, Almalki MA (2015) Isolation and characterization of an endophytic bacterium, Bacillus megaterium BMN1, associated with root-nodules of Medicago sativa $\mathrm{L}$. growing in Al-Ahsaa region, Saudi Arabia. Ann Microbiol 65:10171026. https://doi.org/10.1007/s13213-014-0946-4

Kim SJ, Lee JC, Han SI, Whang KS (2016) Halobacillus salicampi sp. nov., a moderately halophilic bacterium isolated from a solar saltern sediment. Antonie van Leeuwenhoek. Int J Gen Mol Microbiol 109:713-720. https://doi. org/10.1007/s10482-016-0672-y

Kimura N (2018) Novel biological resources screened from uncultured bacteria by a metagenomic method. Elsevier Inc.

Kirchner M, Schneider S (2017) Gene expression control by Bacillus anthracis purine riboswitches. RNA 23:762-769. https://doi.org/10.1261/rna.058792.116

Kofoed EM, Yan D, Katakam AK, Reichelt M, Lin B, Kim J, Park S, Date SV, Monk IR, Xu M, Austin CD, Maurer T, Tan MW (2016) De novo guanine biosynthesis but not the riboswitchregulated purine salvage pathway is required for Staphylococcus aureus infection in vivo. J Bacteriol 198: 2001-2015. https://doi.org/10.1128/JB.00051-16

Kong Z, Deng Z, Glick BR, Wei G, Chou M (2017) A nodule endophytic plant growth-promoting Pseudomonas and its effects on growth, nodulation and metal uptake in Medicago lupulina under copper stress. Ann Microbiol 67: 49-58. https://doi.org/10.1007/s13213-016-1235-1

Kotb E (2016) Improvement of uricase production from Bacillus subtilis RNZ-79 by solid state fermentation of shrimp shell wastes. Biologia (Bratisl) 71:229-238. https://doi. org/10.1515/biolog-2016-0040

Kou D, Peng Y, Wang G, Ding J, Chen Y, Yang G, Fang K, Liu L, Zhang B, Müller C, Zhang J, Yang Y (2018) Diverse responses of belowground internal nitrogen cycling to increasing aridity. Soil Biol Biochem 116:189-192. https://doi. org/10.1016/j.soilbio.2017.10.010
Krol E, Becker A (2011) ppGpp in Sinorhizobium meliloti: biosynthesis in response to sudden nutritional downshifts and modulation of the transcriptome. Mol Microbiol 81:12331254. https://doi.org/10.1111/j.1365-2958.2011.07752.x

Kruasuwan W, Thamchaipenet A (2016) Diversity of culturable plant growth-promoting bacterial endophytes associated with sugarcane roots and their effect of growth by co-inoculation of Diazotrophs and Actinomycetes. J Plant Growth Regul 35: 1074-1087. https://doi.org/10.1007/s00344-016-9604-3

Laney JP, Morse DP (2017) Sensitive and specific detection of ligands using engineered riboswitches. FASEB J 31:907

Lee SD (2008) Jiangella alkaliphila sp. nov., an actinobacterium isolated from a cave. Int J Syst Evol Microbiol 58:11761179. https://doi.org/10.1099/ijs.0.65479-0

Lee SD (2013) Angustibacter peucedani sp. nov., isolated from rhizosphere soil. Int J Syst Evol Microbiol 63:744-750. https://doi.org/10.1099/ijs.0.042275-0

Leimkühler S, Kern M, Solomon PS, McEwan AG, Schwarz G, Mendel RR, Klipp W (1998) Xanthine dehydrogenase from the phototrophic purple bacterium Rhodobacter capsulatus is more similar to its eukaryotic counterparts than to prokaryotic molybdenum enzymes. Mol Microbiol 27:853-869. https://doi.org/10.1046/j.1365-2958.1998.00733.x

Leite J, Fischer D, Rouws LFM, Fernandes-Júnior PI, Hofmann A, Kublik S, Schloter M, Xavier GR, Radl V (2017) Cowpea nodules harbor non-rhizobial bacterial communities that are shaped by soil type rather than plant genotype. Front Plant Sci 7:2064. https://doi.org/10.3389/fpls.2016.02064

Lescano C, Martini C, González C (2016) Allantoin accumulation mediated by allantoinase downregulation and transport by Ureide Permease 5 confers salt stress tolerance to Arabidopsis plants. Plant Mol Biol 91:581-595

Li Y, Jin Z, Yu X, Allewell NM, Tuchman M, Shi D (2011) The ygeW encoded protein from Escherichia coli is a knotted ancestral catabolic transcarbamylase. Proteins Struct Funct Bioinf 79:2327-2334. https://doi.org/10.1002/prot.23043

Li B, Zhao Y, Liu C, Chen Z, Zhou D (2014) Molecular pathogenesis of Klebsiella pneumoniae. Future Microbiol 9:10711081. https://doi.org/10.2217/fmb.14.48

Li YH, Wang R, Zhang XX, Young JPW, Wang ET, Sui XH, Chen WX (2015) Bradyrhizobium guangdongense sp. nov. and Bradyrhizobium guangxiense sp. nov., isolated from effective nodules of peanut. Int J Syst Evol Microbiol 65:4655-4661. https://doi.org/10.1099/ijsem.0.000629

Li Y, Li X, Liu Y, Wang ET, Ren C, Liu W, Xu H, Wu H, Jiang N, Li Y, Zhang X, Xie Z (2016a) Genetic diversity and community structure of rhizobia nodulating Sesbania cannabina in saline-alkaline soils. Syst Appl Microbiol 39:195-202. https://doi.org/10.1016/j.syapm.2016.02.004

Li Y, Wang ET, Liu Y, Li X, Yu B, Ren C, Liu W, Li Y, Xie Z (2016b) Rhizobium anhuiense as the predominant microsymbionts of Lathyrus maritimus along the Shandong Peninsula seashore line. Syst Appl Microbiol 39:384-390. https://doi.org/10.1016/j.syapm.2016.07.001

Li Z, Lin M, Jiang X, Lai X, Xu X (2017) Optimization of culture conditions for production of xanthine oxidase by Arthrobacter sp. MU12. Asia Pac Eng Technol Conf:18131822. https://doi.org/10.12783/dtetr/apetc2017/11387

Lin DX, Wang ET, Tang H, Han TX, He YR, Guan SH, Chen WX (2008) Shinella kummerowiae sp. nov., a symbiotic bacterium isolated from root nodules of the herbal legume 
Kummerowia stipulacea. Int J Syst Evol Microbiol 58:14091413. https://doi.org/10.1099/ijs.0.65723-0

Lin SY, Liu YC, Hameed A, Hsu YH, Huang HI, Lai WA, Young CC (2016) Azospirillum agricola sp. nov., a nitrogen-fixing species isolated from cultivated soil. Int J Syst Evol Microbiol 66:1453-1458. https://doi.org/10.1099 ijsem.0.000904

Liu S (2014) Proteomic analyses of ethanol tolerance in Lactobacillus buchneri NRRL B-30929. Proteomics 14: 2540-2544. https://doi.org/10.1002/pmic.201300538

Liu R, Zhang Y, Chen P, Lin H, Ye G, Wang Z, Ge C, Zhu B, Ren D (2017a) Genomic and phenotypic analyses of Pseudomonas psychrotolerans PRS08-11306 reveal a turnerbactin biosynthesis gene cluster that contributes to nitrogen fixation. J Biotechnol 253:10-13. https://doi. org/10.1016/j.jbiotec.2017.05.012

Liu Y, Lardi M, Pedrioli A, Eberl L, Pessi G (2017b) NtrCdependent control of exopolysaccharide synthesis and motility in Burkholderia cenocepacia H111. PLoS One 12:1-22. https://doi.org/10.1371/journal.pone.0180362

Lòpez-Fernàndez S, Mazzoni V, Pedrazzoli F, Pertot I, Campisano A (2017) A phloem-feeding insect transfers bacterial endophytic communities between grapevine plants. Front Microbiol 8:1-17. https://doi.org/10.3389/fmicb.2017.00834

López-López A, Rogel MA, Ormeño-Orrillo E, Martínez-Romero J, Martínez-Romero E (2010) Phaseolus vulgaris seed-borne endophytic community with novel bacterial species such as Rhizobium endophyticum sp. nov. Syst Appl Microbiol 33: 322-327. https://doi.org/10.1016/j.syapm.2010.07.005

Loveridge EJ, Jones C, Bull MJ, Moody SC, Kahl MW, Khan Z, Neilson L, Tomeva M, Adams SE, Wood AC, RodriguesMartin D, Pinel I, Parkhill J, Mahenthiralingam E, Crosby J (2017) Reclassification of the specialized metabolite producer Pseudomonas mesoacidophila ATCC 31433 as a member of the Burkholderia cepacia complex. J Bacteriol 199: e00125-e00117. https://doi.org/10.1128/JB.00125-17

Lu J, Yang F, Wang S, Ma H, Liang J, Chen Y (2017) Co-existence of rhizobia and diverse non-rhizobial bacteria in the rhizosphere and nodules of Dalbergia odorifera seedlings inoculated with Bradyrhizobium elkanii, Rhizobium multihospitium-like and Burkholderia pyrrocinia-like. Front Microbiol 8:2255. https://doi.org/10.3389/fmicb.2017.02255

Luis Cabrera-Ponce J, Lopez L, Leon-Ramirez GC, Jofre-Garfias AE, Verver-y-Vargas A (2015) Stress induced acquisition of somatic embryogenesis in common bean Phaseolus vulgaris L. Protoplasma 252:559-570. https://doi.org/10.1007 /s00709-014-0702-4

Ma P, Patching SG, Ivanova E, Baldwin JM, Sharples D, Baldwin SA, Henderson PJF (2016) Allantoin transport protein, Pucl, from Bacillus subtilis: evolutionary relationships, amplified expression, activity and specificity. Microbiology 162:823836. https://doi.org/10.1099/mic.0.000266

Manju J, Prabakaran P (2016) Isolation of nodule bacteria from Aeschynomene indica and screening of its efficiency on PHB production. Int J Curr Microbiol Appl Sci 5:791-801. https://doi.org/10.20546/ijcmas.2016.508.088

Mantelin S, Fischer-Le Saux M, Zakhia F, Béna G, Bonneau S, Jeder H, de Lajudie P, Cleyet-Marel JC (2006) Emended description of the genus Phyllobacterium and description of four novel species associated with plant roots: Phyllobacterium bourgognense sp. nov., Phyllobacterium ifriqiyense sp. nov., Phyllobacterium leguminum sp. nov. Int J Syst Evol Microbiol 56:827-839. https://doi. org/10.1099/ijs.0.63911-0

Maroniche GA, García JE, Salcedo F, Creus CM (2017) Molecular identification of Azospirillum spp.: limitations of 16S rRNA and qualities of rpo D as genetic markers. Microbiol Res 195: 1-10. https://doi.org/10.1016/j.micres.2016.11.009

Martin R, Riley PS, Hollis DG, Weaver RE, Krichevsky MI, Al MET (1981) Characterization of some groups of gramnegative nonfermentative bacteria by the carbon source alkalinization technique. J Clin Microbiol 14:39-47

Martínez-Gómez AI, Soriano-Maldonado P, Andújar-Sánchez M, Clemente-Jiménez JM, Rodríguez-Vico F, Neira JL, Las Heras-Vázquez FJ, Martínez-Rodríguez S (2014) Biochemical and mutational studies of allantoinase from Bacillus licheniformis CECT 20T. Biochimie 99:178-188. https://doi.org/10.1016/j.biochi.2013.12.002

Martínez-Hidalgo P, Hirsch AM (2017) The nodule microbiome: $\mathrm{N}_{2}$-fixing rhizobia do not live alone. Phytobiomes 1:70-82. https://doi.org/10.1094/PBIOMES-12-16-0019-RVW

Martins da Costa E, Azarias Guimarães A, Soares de Carvalho T, Louzada Rodrigues T, de Almeida Ribeiro PR, Lebbe L, Willems A, de Souza Moreira FM (2018) Bradyrhizobium forestalis sp. nov., an efficient nitrogen-fixing bacterium isolated from nodules of forest legume species in the Amazon. Arch Microbiol. https://doi.org/10.1007/s00203018-1486-2

Matiasovicova J, Havlickova H, Sisak F, Pilousova L, Rychlik I (2011) allB, allantoin utilisation and Salmonella enterica serovar Enteritidis and Typhimurium colonisation of poultry and mice. Folia Microbiol (Praha) 56:264-269. https://doi. org/10.1007/s12223-011-0034-0

Matiollo C, Vernal J, Ecco G, Bertoldo JB, Razzera G, de Souza EM, Pedrosa FO, Terenzi H (2009) A transthyretin-related protein is functionally expressed in Herbaspirillum seropedicae. Biochem Biophys Res Commun 387:712716. https://doi.org/10.1016/j.bbrc.2009.07.094

Meyer N, Welp G, Bornemann L, Amelung W (2017) Microbial nitrogen mining affects spatio-temporal patterns of substrateinduced respiration during seven years of bare fallow. Soil Biol Biochem 104:175-184. https://doi.org/10.1016/J. SOILBIO.2016.10.019

Michel DC, Passos SR, Simões-Araujo JL, Baraúna AC, da Silva K, Parma MM, Melo IS, De Meyer SE, O’Hara G, Zilli JE (2017) Bradyrhizobium centrolobii and Bradyrhizobium macuxiense sp. nov. isolated from Centrolobium paraense grown in soil of Amazonia, Brazil. Arch Microbiol 199:657664. https://doi.org/10.1007/s00203-017-1340-y

Minami T, Anda M, Mitsui H, Sugawara M, Kaneko T, Sato S, Ikeda S, Okubo T, Tsurumaru H, Minamisawa K (2016) Metagenomic analysis revealed methylamine and ureide utilization of soybean-associated Methylobacterium. Microbes Environ 31:268-278. https://doi.org/10.1264/jsme2. ME16035

Møller HD, Andersen KS, Regenberg B (2013) A model for generating several adaptive phenotypes from a single genetic event. Commun Integr Biol 6:e23933. https://doi. org/10.4161/cib.23933

Muresu R, Polone E, Sulas L, Baldan B, Tondello A, Delogu G, Cappuccinelli P, Alberghini S, Benhizia Y, Benhizia H, Benguedouar A, Mori B, Calamassi R, Dazzo FB, Squartini 
A (2008) Coexistence of predominantly nonculturable rhizobia with diverse, endophytic bacterial taxa within nodules of wild legumes. FEMS Microbiol Ecol 63:383-400. https://doi.org/10.1111/j.1574-6941.2007.00424.x

Naito T, Sachuronggui UM, Maeda I (2016) Light-enhanced bioaccumulation of molybdenum by nitrogen-deprived recombinant anoxygenic photosynthetic bacterium Rhodopseudomonas palustris. Biosci Biotechnol Biochem $80: 407-413$. https://doi.org/10.1080 /09168451.2015.1086260

Nalubega F, Meklat A, Mellouk I, ChaabaneChaouch F, Verheecke C, Bouras N, Mokrane S, Mathieu F, Sabaou N (2016) Taxonomy and antagonistic activity of A12, a new Streptomyces strain isolated from Ugandan soil. ElWahat pour les Rech les Etudes 9:1-11

Nanda P, Jagadeesh Babu PE (2014) Isolation, screening and production studies of uricase producing bacteria from poultry sources. Prep Biochem Biotechnol 44:811-821. https://doi. org/10.1080/10826068.2013.867875

Nascimento FX, Rossi MJ, Glick BR (2018) Ethylene and 1aminocyclopropane-1-carboxylate (ACC) in plant-bacterial interactions. Front Plant Sci 9:1-17. https://doi.org/10.3389 /fpls.2018.00114

Navone L, Casati P, Licona-Cassani C, Marcellin E, Nielsen LK, Rodriguez E, Gramajo H (2014) Allantoin catabolism influences the production of antibiotics in Streptomyces coelicolor. Appl Microbiol Biotechnol 98:351-360. https://oi.org/10.1007/s00253-013-5372-1

Naylor D, Coleman-Derr D (2018) Drought stress and rootassociated bacterial communities. Front Plant Sci 8:1-16. https://doi.org/10.3389/fpls.2017.02223

Neuvonen M-M, Tamarit D, Näslund K, Liebig J, Feldhaar H, Moran NA, Guy L, Andersson SGE (2016) The genome of Rhizobiales bacteria in predatory ants reveals urease gene functions but no genes for nitrogen fixation. Sci Rep 6: 39197. https://doi.org/10.1038/srep39197

Nguyen LTT, Osanai Y, Lai K, Anderson IC, Bange MP, Tissue DT, Singh BK (2018) Responses of the soil microbial community to nitrogen fertilizer regimes and historical exposure to extreme weather events: flooding or prolonged-drought. Soil Biol Biochem 118:227-236. https://doi.org/10.1016/j. soilbio.2017.12.016

Nikkhah A (2016) 350 estimates of duodenal microbial protein in free housed dairy cows fed total mixed ration vs. component diet. J Anim Sci 94:164-164. https://doi.org/10.2527 /msasas2016-350

Nile SH, Nile AS, Keum YS, Sharma K (2017) Utilization of quercetin and quercetin glycosides from onion (Allium cepa L.) solid waste as an antioxidant, urease and xanthine oxidase inhibitors. Food Chem 235:119-126. https://doi.org/10.1016 /j.foodchem.2017.05.043

Numan M, Bashir S, Khan Y, Mumtaz R, Shinwari ZK, Khan AL, Khan A, Al-Harrasi A (2018) Plant growth promoting bacteria as an alternative strategy for salt tolerance in plants: a review. Microbiol Res 209:21-32. https://doi.org/10.1016/j. micres.2018.02.003

Ofosu-Budu KG, Saneoka H, Fujita K (1995) Factors controlling the release of nitrogenous compounds from roots of soybean. Soil Sci Plant Nutr 41:625-633. https://doi.org/10.1080 /00380768.1995.10417013
Österman J, Marsh J, Laine PK, Zeng Z, Alatalo E, Sullivan JT, Young JPW, Thomas-Oates J, Paulin L, Lindström K (2014) Genome sequencing of two Neorhizobium galegae strains reveals a noeT gene responsible for the unusual acetylation of the nodulation factors. BMC Genomics 15:500. https://doi. org/10.1186/1471-2164-15-500

Otanga RR, Yobo KS, Laing MD (2018) Response of two wheat cultivars to inoculation of diazotrophic bacteria in combination with reduced nitrogen fertilisation under field conditions. S Afr J Plant Soil 1862:1-8. https://doi.org/10.1080 /02571862.2017.1419387

Ozdemir-Kocak F, Isik K, Veyisoglu A, Tatar D, Sahin N (2014) Nonomuraea muscovyensis sp. nov., isolated from soil. Int J Syst Evol Microbiol 64:2467-2472. https://doi.org/10.1099 /ijs.0.061291-0

Ozdemir-Kocak F, Saygin H, Saricaoglu S, Cetin D, Guven K, Spröer C, Schumann P, Klenk H-P, Sahin N, Isik K (2017) Kribbella soli sp. nov., isolated from soil. Antonie Van Leeuwenhoek 110:641-649. https://doi.org/10.1007 /s10482-017-0830-x

Palaniappan P, Chauhan PS, Saravanan VS, Anandham R, Sa T (2010) Isolation and characterization of plant growth promoting endophytic bacterial isolates from root nodule of Lespedeza sp. Biol Fertil Soils 46:807-816. https://doi. org/10.1007/s00374-010-0485-5

Pandya M, Naresh Kumar G, Rajkumar S (2013) Invasion of rhizobial infection thread by non-rhizobia for colonization of Vigna radiata root nodules. FEMS Microbiol Lett 348:5865. https://doi.org/10.1111/1574-6968.12245

Pandya M, Rajput M, Rajkumar S (2015) Exploring plant growth promoting potential of non rhizobial root nodules endophytes of Vigna radiata. Microbiology 84:80-89. https://doi. org/10.1134/S0026261715010105

Papakostas K, Frillingos S (2012) Substrate selectivity of YgfU, a uric acid transporter from Escherichia coli. J Biol Chem 287: 15684-15695. https://doi.org/10.1074/jbc.M112.355818

Papakostas K, Botou M, Frillingos S (2013) Functional identification of the hypoxanthine/guanine transporters $\mathrm{YjcD}$ and YgfQ and the adenine transporters PurP and YicO of Escherichia coli K-12. J Biol Chem 288:36827-36840. https://doi.org/10.1074/jbc.M113.523340

Patching SG (2017) Synthesis, NMR analysis and applications of isotope-labelled hydantoins. J Diagn Imaging Ther 4:3-26. https://doi.org/10.17229/jdit.2017-0225-026

Patel JK, Archana G (2017) Diverse culturable diazotrophic endophytic bacteria from Poaceae plants show crosscolonization and plant growth promotion in wheat. Plant Soil 417:99-116. https://doi.org/10.1007/s11104-017-32447

Peix A, Ramírez-Bahena MH, Velázquez E, Bedmar EJ (2015) Bacterial associations with legumes. CRC Crit Rev Plant Sci 34:17-42. https://doi.org/10.1080/07352689.2014.897899

Peng WF, Huang CY (2014) Allantoinase and dihydroorotase binding and inhibition by flavonols and the substrates of cyclic amidohydrolases. Biochimie 101:113-122. https://doi.org/10.1016/j.biochi.2014.01.001

Peredo EL, Simmons SL (2018) Leaf-FISH: microscale imaging of bacterial taxa on phyllosphere. Front Microbiol 8:1-14. https://doi.org/10.3389/fmicb.2017.02669

Petridis M, Benjak A, Cook GM (2015) Defining the nitrogen regulated transcriptome of Mycobacterium smegmatis using 
continuous culture. BMC Genomics 16:821. https://doi. org/10.1186/s12864-015-2051-X

Petridis M, Vickers C, Robson J, McKenzie JL, Bereza M, Sharrock A, Aung HL, Arcus VL, Cook GM (2016) Structure and function of AmtR in Mycobacterium smegmatis: implications for post-transcriptional regulation of urea metabolism through a small antisense RNA. J Mol Biol 428:4315-4329. https://doi.org/10.1016/j. jmb.2016.09.009

Pineda M, Fernandez E, Cardenas J (1984) Urate oxidase of Chlamydomonas reinhardii. Physiol Plant 62:453-457. https://doi.org/10.1111/j.1399-3054.1984.tb04602.x

Prasad PVD (1983) Hypoxanthine and allantoin as nitrogen sources for the growth of some freshwater green algae. New Phytol 93:575-580. https://doi.org/10.1111/j.14698137.1983.tb02708.x

Qin S, Zhao G-Z, Li J, Zhu W-Y, Xu L-H, Li W-J (2009) Jiangella alba sp. nov., an endophytic actinomycete isolated from the stem of Maytenus austroyunnanensis. Int J Syst Evol Microbiol 59:2162-2165. https://doi.org/10.1099 /ijs.0.009001-0

Ramírez-Bahena MH, Flores-Félix JD, Chahboune R, Toro M, Velázquez E, Peix A (2016) Bradyrhizobium centrosemae (symbiovar centrosemae) sp. nov., Bradyrhizobium americanum (symbiovar phaseolarum) sp. nov. and a new symbiovar (tropici) of Bradyrhizobium viridifuturi establish symbiosis with Centrosema species na. Syst Appl Microbiol 39:378-383. https://doi.org/10.1016/j.syapm.2016.06.001

Ranf S (2017) Sensing of molecular patterns through cell surface immune receptors. Curr Opin Plant Biol 38:68-77. https://doi.org/10.1016/j.pbi.2017.04.011

Rauwane ME, Marais LM, Oladipo OG, Bezuidenhout CC, Maboeta MS (2017) Spatio-seasonal dynamics of bacteria and metal composition of a platinum mine tailings dam, Rustenburg, South Africa. S Afr J Plant Soil 1862:1-7. https://doi.org/10.1080/02571862.2017.1345017

Ravichandran R, Hemaasri S, Cameotra SS, Jayaprakash NS (2015) Purification and characterization of an extracellular uricase from a new isolate of Sphingobacterium thalpophilum (VITPCB5). Protein Expr Purif 114:136-142. https://doi.org/10.1016/j.pep.2015.06.017

Raymond S, Tocilj A, Ajamian E, Li Y, Hung MN, Matte A, Cygler M (2005) Crystal structure of ureidoglycolate hydrolase (AllA) from Escherichia coli O157:H7. Proteins Struct Funct Genet 61:454-459. https://doi.org/10.1002/prot.20537

Raziq N, Saeed M, Ali MS, Zafar S, Shahid M, Lateef M (2017) A new glycosidic antioxidant from Ranunculus muricatus L. (Ranunculaceae) exhibited lipoxygenasae and xanthine oxidase inhibition properties. Nat Prod Res 31:1251-1257. https://doi.org/10.1080/14786419.2016.1236098

Rebollar EA, Sandoval-Castellanos E, Roessler K, Gaut BS, Alcaraz LD, Benítez M, Escalante AE (2017) Seasonal changes in a maize-based polyculture of Central Mexico reshape the co-occurrence networks of soil bacterial communities. Front Microbiol 8:2478. https://doi.org/10.3389 /fmicb.2017.02478

Reece P, Toth D, Dawes EA (1976) Fermentation of purines and their effect on the adenylate energy charge and viability of starved Peptococcus pravotii. J Gen Microbiol 97:63-71. https://doi.org/10.1099/00221287-97-1-63
Ren C, Chen J, Lu X, Doughty R, Zhao F, Zhong Z, Han X, Yang G, Feng Y, Ren G (2018) Responses of soil total microbial biomass and community compositions to rainfall reductions. Soil Biol Biochem 116:4-10. https://doi.org/10.1016/j. soilbio.2017.09.028

Reschke S, Mebs S, Sigfridsson-Clauss KGV, Kositzki R, Leimkühler S, Haumann M (2017) Protonation and sulfido versus oxo ligation changes at the molybdenum cofactor in xanthine dehydrogenase (XDH) variants studied by $\mathrm{x}$-ray absorption spectroscopy. Inorg Chem 56:2165-2176. https://doi.org/10.1021/acs.inorgchem.6b02846

Rivas R, Velázquez E, Willems A, Vizcaíno N, Subba-Rao NS, Mateos PF, Gillis M, Dazzo FB, Martínez-Molina E (2002) A new species of Devosia that forms a unique nitrogen-fixing root-nodule symbiosis with the aquatic legume Neptunia natans (L.f.) Druce. Appl Environ Microbiol 68:52175222. https://doi.org/10.1128/AEM.68.11.5217-5222.2002

Rivas M, Becerra A, Lazcano A (2018) On the early evolution of catabolic pathways: a comparative genomics approach. I. The cases of glucose, ribose, and the nucleobases catabolic routes. J Mol Evol 86:27-46. https://doi.org/10.1007 /s00239-017-9822-8

Rodríguez CE, Mitter B, Barret M, Sessitsch A, Compant S (2018) Commentary: seed bacterial inhabitants and their routes of colonization. Plant Soil 422:129-134. https://doi. org/10.1007/s11104-017-3368-9

Rolli E, Marasco R, Vigani G, Ettoumi B, Mapelli F, Deangelis ML, Gandolfi C, Casati E, Previtali F, Gerbino R, Pierotti Cei F, Borin S, Sorlini C, Zocchi G, Daffonchio D (2015) Improved plant resistance to drought is promoted by the root-associated microbiome as a water stress-dependent trait. Environ Microbiol 17:316-331. https://doi.org/10.1111 /1462-2920.12439

Romero AM, Vega D, Correa OS (2014) Azospirillum brasilense mitigates water stress imposed by a vascular disease by increasing xylem vessel area and stem hydraulic conductivity in tomato. Appl Soil Ecol 82:38-43. https://doi.org/10.1016 j.apsoil.2014.05.010

Rouf MA (1968) Degradation of uric acid by certain aerobic bacteria. J Bacteriol 96:617-622

Safronova VI, Kuznetsova IG, Sazanova AL, Belimov AA, Andronov EE, Chirak ER, Osledkin YS, Onishchuk OP, Kurchak ON, Shaposhnikov AI, Willems A, Tikhonovich IA (2017) Microvirga ossetica sp. nov., a species of rhizobia isolated from root nodules of the legume species Vicia alpestris Steven. Int J Syst Evol Microbiol 67:94-100. https://doi.org/10.1099/ijsem.0.001577

Saïdi S, Chebil S, Gtari M, Mhamdi R (2013) Characterization of root-nodule bacteria isolated from Vicia faba and selection of plant growth promoting isolates. World J Microbiol Biotechnol 29:1099-1106. https://doi.org/10.1007/s11274013-1278-4

Salas JA, Eliar DJ (1985) Uric acid and allantoin uptake by Bacillus fastidiosus spores. FEBS 183:256-259. https://oi. org/10.1016/0014-5793(85)80788-2

Samaha HAM, Ali NAA, Mansi I, Abu-El-Halawa R (2017) Antimicrobial, antiradical and xanthine oxidase inhibitory activities of Juniperus procera plant extracts from Albaha. World J Pharm Pharm Sci 6:232-242. https://doi. org/10.20959/wjpps20172-8579 
Santhanam R, Okoro CK, Rong X, Huang Y, Bull AT, Andrews BA, Asenjo JA, Weon HY, Goodfellow M (2012) Streptomyces deserti sp. nov., isolated from hyper-arid Atacama Desert soil. Antonie van Leeuwenhoek 101:575581. https://doi.org/10.1007/s10482-011-9672-0

Saricaoglu S, Isik K, Veyisoglu A, Saygin H, Cetin D, Guven K, Sproer C, Klenk H-P, Sahin N (2014) Streptomyces burgazadensis sp. nov., isolated from soil. Int J Syst Evol Microbiol 64:4043-4048. https://doi.org/10.1099 /ijs.0.065870-0

Self WT (2002) Regulation of purine hydroxylase and xanthine dehydrogenase from Clostridium purinolyticum in response to purines, selenium, and molybdenum. J Bacteriol 184: 2039-2044. https://doi.org/10.1128/JB.184.7.20392044.2002

Selvakumar G, Kundu S, Gupta AD, Shouche YS, Gupta HS (2008) Isolation and characterization of nonrhizobial plant growth promoting bacteria from nodules of Kudzu (Pueraria thunbergiana) and their effect on wheat seedling growth. Curr Microbiol 56:134-139. https://doi.org/10.1007 /s00284-007-9062-z

Senga R-A, Alegria Terrazas S, Balbirnie K, Blank M, Janiak A, Szarejko I, Chmielewska B, Karcz J, Morris J, Hedley PE, George TS, Bulgarelli D (2017) Root hair mutations displace the barley rhizosphere microbiota. Front Plant Sci 8:1094. https://doi.org/10.3389/fpls.2017.01094

Serraj R, Sinclair TR (2003) Evidence that carbon dioxide enrichment alleviates ureide-induced decline of nodule nitrogenase activity. Ann Bot 91:85-89. https://doi.org/10.1093 /aob/mcg012

Serraj R, Sinclair TR, Purcell LC (1999) Symbiotic $\mathrm{N}_{2}$ fixation response to drought. J Exp Bot 50:143-155. https://doi. org/10.1093/jxb/50.331.143

Serventi F, Ramazzina I, Lamberto I, Puggioni V, Gatti R, Percudani R (2010) Chemical basis of nitrogen recovery through the ureide pathway: formation and hydrolysis of Sureidoglycine in plants and bacteria. ACS Chem Biol 5:203214. https://doi.org/10.1021/cb900248n

Shameer S, Prasad TNVKV (2018) Plant growth promoting rhizobacteria for sustainable agricultural practices with special reference to biotic and abiotic stresses. Plant Growth Regul 84:603-615. https://doi.org/10.1007/s10725-0170365-1

Sharma NK, Thakur S, Thakur N, Savitri BTC (2016) Thermostable xanthine oxidase activity from Bacillus pumilus RL-2d isolated from Manikaran thermal spring: production and characterization. Indian J Microbiol 56:8898. https://doi.org/10.1007/s12088-015-0547-3

Sharples JM, Cairney JWG (1997) Organic nitrogen utilization by an unidentified mycobiont isolated from mycorrhizas of Pisonia grandis. Mycol Res 101:315-318. https://doi. org/10.1017/S0953756296002584

Shorey E (1947) The presence of allantoin in soils. Soil Sci 45: $177-183$

Silva UC, Medeiros JD, Leite LR, Morais DK, Cuadros-Orellana S, Oliveira CA, de Paula Lana UG, Gomes EA, Dos Santos VL (2017a) Long-term rock phosphate fertilization impacts the microbial communities of maize rhizosphere. Front Microbiol 8:1266. https://doi.org/10.3389 /FMICB.2017.01266
Silva PRAD, Simões-Araújo JL, Vidal MS, Cruz LM, de Souza EM, Baldani JI (2017b) Draft genome sequence of Paraburkholderia tropica Ppe8 strain, a sugarcane endophytic diazotrophic bacterium. Braz J Microbiol. https://doi. org/10.1016/J.BJM.2017.07.005

Simões-Araújo JL, Rumjanek NG, Xavier GR, Zilli JÉ (2017) Draft genome sequence of Bradyrhizobium manausense strain BR 3351T, an effective symbiont isolated from Amazon rainforest. Braz J Microbiol 48:610-611. https://doi.org/10.1016/j.bjm.2016.10.025

Simon J, Dannenmann M, Pena R, Gessler A, Rennenberg H (2017) Nitrogen nutrition of beech forests in a changing climate: importance of plant-soil-microbe water, carbon, and nitrogen interactions. Plant Soil 418:89-114

Sivapragasam S, Grove A (2016) Streptomyces coelicolor XdhR is a direct target of (p)ppGpp that controls expression of genes encoding xanthine dehydrogenase to promote purine salvage. Mol Microbiol 100:701-718. https://doi.org/10.1111 /mmi.13342

Soe KM, Bhromsiri A, Karladee D, Yamakawa T (2012) Effects of endophytic actinomycetes and Bradyrhizobium japonicum strains on growth, nodulation, nitrogen fixation and seed weight of different soybean varieties. Soil Sci Plant Nutr 58: 319-325. https://doi.org/10.1080/00380768.2012.682044

Soleimani R, Alikhani HA, Towfighi H (2017) The ability of ACC deaminase production in isolated bacteria from drought, saline and saline-sodic soils and selection of the most efficient bacteria. Biol J Microorg 6:53-66

Soni R, Yadav SK, Rajput AS (2018) ACC-deaminase producing rhizobacteria: prospects and application as stress busters for stressed agriculture. pp 161-175

Steenkamp ET, van Zyl E, Beukes CW, Avontuur JR, Chan WY, Palmer M, Mthombeni LS, Phalane FL, Sereme TK, Venter SN (2015) Burkholderia kirstenboschensis sp. nov. nodulates papilionoid legumes indigenous to South Africa. Syst Appl Microbiol 38:545-554. https://doi.org/10.1016/j. syapm.2015.09.003

Sturz AV, Christie BR, Matheson BG, Nowak J (1997) Biodiversity of endophytic bacteria which colonize red clover nodules, roots, stems and foliage and their influence on host growth. Biol Fertil Soils 25:13-19. https://doi. org/10.1007/s003740050273

Sun M (2009) Molecular phylogenetic identification of endophytic fungi isolated from three Artemisia species. Fungal Divers 36:69-88

Sun B, Kong C, Wang P, Qu R (2012) Response and relation of allantoin production in different rice cultivars to competing barnyardgrass. Plant Ecol 213:1917-1926

Suneja P, Duhan JS, Bhutani N, Dudeja SS (2017) Recent biotechnological approaches to study taxonomy of legume nodule forming rhizobia. In: Plant biotechnology: recent advancements and developments. Springer Singapore, Singapore, pp 101-124

Takagi H, Ishiga Y, Watanabe S, Konishi T, Egusa M, Akiyoshi N, Matsuura T, Mori IC, Hirayama T, Kaminaka H, Shimada H, Sakamoto A (2016) Allantoin, a stress-related purine metabolite, can activate jasmonate signaling in a MYC2-regulated and abscisic acid-dependent manner. J Exp Bot 67:25192532. https://doi.org/10.1093/jxb/erw071 
Tatar D, Sahin N (2015) Streptomyces seymenliensis sp. nov., isolated from soil. Antonie Van Leeuwenhoek 107:411418. https://doi.org/10.1007/s10482-014-0339-5

Tatar D, Guven K, Inan K, Cetin D, Belduz AO, Sahin N (2016) Streptomonospora tuzyakensis sp. nov., a halophilic actinomycete isolated from saline soil. Antonie van Leeuwenhoek. Int J Gen Mol Microbiol 109:35-41. https://doi.org/10.1007 /s10482-015-0607-z

Tian G, Wang Q, Wei X, Ma X, Chen S (2017) Glutamate dehydrogenase (RocG) in Bacillus licheniformis WX-02: enzymatic properties and specific functions in glutamic acid synthesis for poly- $\gamma$-glutamic acid production. Enzym Microb Technol 99:9-15. https://doi.org/10.1016/j. enzmictec.2017.01.002

Trabelsi D, Chihaoui SA, Mhamdi R (2017) Nodules and roots of Vicia faba are inhabited by quite different populations of associated bacteria. Appl Soil Ecol 119:72-79. https://doi. org/10.1016/j.apsoil.2017.06.002

Tran PN, Savka MA, Gan HM (2017) In-silico taxonomic classification of 373 genomes reveals species misidentification and new genospecies within the genus Pseudomonas. Front Microbiol 8:1296. https://doi.org/10.3389/fmicb.2017.01296

Trujillo ME, Bacigalupe R, Pujic P, Igarashi Y, Benito P, Riesco R, Médigue C, Normand P (2014) Genome features of the endophytic Actinobacterium Micromonospora lupini strain lupac 08: on the process of adaptation to an endophytic life style? PLoS One 9:e108522. https://doi.org/10.1371/journal. pone. 0108522

Trujillo ME, Riesco R, Benito P, Carro L (2015) Endophytic actinobacteria and the interaction of Micromonospora and nitrogen fixing plants. Front Microbiol 6:1341

Urano H, Umezawa Y, Yamamoto K, Ishihama A, Ogasawara H (2015) Cooperative regulation of the common target genes between $\mathrm{H}_{2} \mathrm{O}_{2}$-sensing YedVW and $\mathrm{Cu}^{2+}$-sensing CusSR in Escherichia coli. Microbiology 161:729-738. https://doi. org/10.1099/mic.0.000026

van der Drift C, de Windt FE (1983) Glyoxylate conversion by Hyphomicrobium species grown on allantoin as nitrogen source. Antonie Van Leeuwenhoek 49:167-172. https://doi. org/10.1007/BF00393675

van der Drift L, Vogels GD, van der Drift C (1975) Allantoin racemase: a new enzyme from pseudomonas species. Biochim Biophys Acta 391:240-248. https://doi. org/10.1016/0005-2744(75)90170-9

Vander Wauven C, Simon J-P, Slos P, Stalon V (1986) Control of enzyme synthesis in the oxalurate catabolic pathway of Streptococcus faecalis ATCC 11700: evidence for the existence of a third carbamate kinase. Arch Microbiol 145:386390. https://doi.org/10.1007/BF00470876

Vargas LK, Volpiano CG, Lisboa BB, Giongo A, Beneduzi A (2017) Potential of rhizobia as plant growth-promoting rhizobacteria. In: Zaidi A, Khan MS, Musarrat J (eds) Microbes for legume improvement. Springer International Publishing, Cham, pp 153-174

Velázquez E, Carro L, Flores-Félix JD, Martínez-Hidalgo P, Menéndez E, Ramírez-Bahena H, Mulas R, GonzálezAndrés F, Martínez-Molina E, Peix A (2017a) The legume nodule microbiome: a source of plant growth-promoting bacteria. In: Kumar V, Kumar M, Sharma S, Prasad R (eds) Probiotics and plant health. Springer Singapore, Singapore, pp 41-70
Velázquez E, García-Fraile P, Ramírez-Bahena M-H, Rivas R, Martínez-Molina E (2017b) Current status of the taxonomy of bacteria able to establish nitrogen-fixing legume symbiosis. In: Microbes for legume improvement. Springer International Publishing, Cham, pp 1-43

Veyisoglu A, Camas M, Tatar D, Guven K, Sazak A, Sahin N (2013) Methylobacterium tarhaniae sp. nov., isolated from arid soil. Int J Syst Evol Microbiol 63:2823-2828. https://doi. org/10.1099/ijs.0.049551-0

Veyisoglu A, Tatar D, Cetin D, Guven K, Sahin N (2014) Streptomyces karpasiensis sp. nov., isolated from soil. Int J Syst Evol Microbiol 64:827-832. https://doi.org/10.1099 /ijs.0.056275-0

Veyisoglu A, Carro L, Guven K, Cetin D, Spröer C, Schumann P, Klenk HP, Goodfellow M, Sahin N (2016a) Micromonospora yasonensis sp. nov., isolated from a Black Sea sediment. Antonie van Leeuwenhoek 109:1019-1028. https://doi.org/10.1007/s10482-016-0701-x

Veyisoglu A, Tatar D, Saygin H, Inan K, Cetin D, Guven K, Tuncer M, Sahin N (2016b) Microvirga makkahensis sp. nov., and Microvirga arabica sp. nov., isolated from sandy arid soil. Antonie Van Leeuwenhoek 109:287-296. https://doi.org/10.1007/s10482-015-0631-z

Volkova YA, Chernoburova EI, Petrova AS, Shtil AA, Zavarzin IV (2017) Reactions of hydrazones derived from oxamic acid thiohydrazides. Phosphorus Sulfur Silicon Relat Elem 192: 237-240. https://doi.org/10.1080/10426507.2016.1250759

Wang P, Kong CH, Hu F, Xu XH (2007) Allantoin involved in species interactions with rice and other organisms in paddy soil. Plant Soil 296:43-51. https://doi.org/10.1007/s11104007-9288-3

Wang P, Kong C, Sun B, Xu X (2010) Allantoin-induced changes of microbial diversity and community in rice soil. Plant Soil 332:357-368. https://doi.org/10.1007/s11104-010-0301-x

Wang J, Zhang J, Ding K, Xin Y, Pang H (2012) Brevundimonas viscosa sp. nov., isolated from saline soil. Int J Syst Evol Microbiol 62:2475-2479. https://doi.org/10.1099 /ijs.0.035352-0

Wang C-H, Zhao T-X, Li M, Zhang C, Xing X-H (2015) Characterization of a novel Acinetobacter baumannii xanthine dehydrogenase expressed in Escherichia coli. Biotechnol Lett 38:337-344. https://doi.org/10.1007 /s10529-015-1986-y

Wang Z, Zhong R, Lai C, Zeng Z, Lian Y, Bai X (2018) Climate change enhances the severity and variability of drought in the Pearl River Basin in South China in the 21st century. Agric For Meteorol 249:149-162. https://doi.org/10.1016/j. agrformet.2017.12.077

Wei X, Xin D, Xin Y, Zhang H, Wang T, Zhang J (2016) Bacillus depressus sp. nov., isolated from soil of a sunflower field. Antonie Van Leeuwenhoek 109:13-20. https://doi. org/10.1007/s10482-015-0605-1

Wekesa C, Muoma J, Ombori O, Maingi J, Okun D, Juma K, Okoth P, Wamalwa E, Kollenberg M (2017) Characterization of rhizosphere bacteria that inhabit common bean nodules in Western Kenya soils. Appl Microbiol Open Access 3:1-7. https://doi.org/10.4172/2471-9315.1000128

Weon HY, Kim BY, Kwon SW, Go SJ, Koo BS, Stackebrandt E (2008) Phenylobacterium composti sp. nov., isolated from cotton waste compost in Korea. Int J Syst Evol Microbiol 58: 2301-2304. https://doi.org/10.1099/ijs.0.65530-0 
Werner AK, Witte C-P (2011) The biochemistry of nitrogen mobilization: purine ring catabolism. Trends Plant Sci 16:381387. https://doi.org/10.1016/j.tplants.2011.03.012

Werner AK, Romeis T, Witte CP (2010) Ureide catabolism in Arabidopsis thaliana and Escherichia coli. Nat Chem Biol 6:19-21. https://doi.org/10.1038/nchembio.265

Wilkinson SP, Grove A (2005) Negative cooperativity of uric acid binding to the transcriptional regulator HucR from Deinococcus radiodurans. J Mol Biol 350:617-630. https://doi.org/10.1016/j.jmb.2005.05.027

Woolfolk CA, Downard JS (1977) Distribution of xanthine oxidase and xanthine dehydrogenase specificity types among bacteria. J Bacteriol 130:1175-1191

Wu S-H, Huang B-H, Huang C-L, Li G, Liao P-C (2018) The aboveground vegetation type and underground soil property mediate the divergence of soil microbiomes and the biological interactions. Microb Ecol 75:434-446. https://doi. org/10.1007/s00248-017-1050-7

Xiao X, Chen W, Zong L, Yang J, Jiao S, Lin Y, Wang E, Wei G (2017) Two cultivated legume plants reveal the enrichment process of the microbiome in the rhizocompartments. Mol Ecol 26:1641-1651. https://doi.org/10.1111/mec.14027

Xie Q, Bao X, Ma Q, Kong F, Zhou M, Yan B, Zhao Y (2018) Verrucosispora rhizosphaerae sp. nov., isolated from mangrove rhizosphere soil. Antonie Van Leeuwenhoek 111:125133. https://doi.org/10.1007/s10482-017-0933-4

Xu L, Shi J, Li C, Zhu S, Li B (2017) Rhizobium hedysari sp. nov., a novel species isolated from a root nodule of Hedysarum multijugum in China. Antonie Van Leeuwenhoek 110:479488. https://doi.org/10.1007/s10482-016-0817-Z

Xu L, Zhang Y, Li C, Wang X, Liu J, Friman V-P (2018) Nocardioides astragali sp. nov., isolated from a nodule of wild Astragalus chrysopterus in northwestern China. Antonie Van Leeuwenhoek. https://doi.org/10.1007/s10482018-1020-1

Xue S, Yang X, Liu G, Gai L, Zhang C, Ritsema CJ, Geissen V (2017) Effects of elevated $\mathrm{CO}_{2}$ and drought on the microbial biomass and enzymatic activities in the rhizospheres of two grass species in Chinese loess soil. Geoderma 286:25-34. https://doi.org/10.1016/J.GEODERMA.2016.10.025

Yan H, Ji ZJ, Jiao YS, Wang ET, Chen WF, Guo BL, Chen WX (2016) Genetic diversity and distribution of rhizobia associated with the medicinal legumes Astragalus spp. and Hedysarum polybotrys in agricultural soils. Syst Appl Microbiol 39:141-149. https://doi.org/10.1016/j. syapm.2016.01.004

Yan J, Li Y, Han XZ, Chen WF, Zou WX, Xie Z, Li M (2017a) Agrobacterium deltaense sp. nov., an endophytic bacteria isolated from nodule of Sesbania cannabina. Arch Microbiol 199:1003-1009. https://doi.org/10.1007/s00203017-1367-0

Yan J, Li Y, Yan H, Chen WF, Zhang X, Wang ET, Han XZ, Xie ZH (2017b) Agrobacterium salinitolerans sp. nov., a salinealkaline-tolerant bacterium isolated from root nodule of Sesbania cannabina. Int J Syst Evol Microbiol 67:19061911. https://doi.org/10.1099/ijsem.0.001885

Yang K, Wei C, Zhao G, Xu Z, Lin S (2016) Dietary supplementation of tannic acid modulates nitrogen excretion pattern and urinary nitrogenous constituents of beef cattle. Livest Sci 191:148-152. https://doi.org/10.1016/j.livsci.2016.07.020
Yoon JH, Lee HB, Yeo SH, Choi JE (2004) Janibacter melonis sp. nov., isolated from abnormally spoiled oriental melon in Korea. Int J Syst Evol Microbiol 54:1975-1980. https://doi. org/10.1099/ijs.0.63167-0

Yoon J-H, Lee M-H, Kang S-J, Park S-Y, Oh T-K (2006) Pedobacter sandarakinus sp. nov., isolated from soil. Int $\mathrm{J}$ Syst Evol Microbiol 56:1273-1277. https://doi.org/10.1099 /ijs.0.64148-0

Yoon J-H, Kang S-J, Park S, Oh T-K (2007) Devosia insulae sp. nov., isolated from soil, and emended description of the genus Devosia. Int J Syst Evol Microbiol 57:1310-1314. https://doi.org/10.1099/ijs.0.65028-0

Zaheer A, Mirza BS, Mclean JE, Yasmin S, Shah TM, Malik KA, Mirza MS (2016) Association of plant growth-promoting Serratia spp. with the root nodules of chickpea. Res Microbiol 167:510-520. https://doi.org/10.1016/j. resmic.2016.04.001

Zai X, Yang Q, Yin Y, Li R, Qian M, Zhao T, Li Y, Zhang J, Fu L, $\mathrm{Xu}$ J, Chen W (2017) Relative quantitative proteomic analysis of Brucella abortus reveals metabolic adaptation to multiple environmental stresses. Front Microbiol 8:2347. https://doi.org/10.3389/fmicb.2017.02347

Zhang YQ, Li WJ, Zhang KY, Tian XP, Jiang Y, Xu LH, Jiang CL, Lai R (2006) Massilia dura sp. nov., Massilia albidiflava sp. nov., Massilia plicata sp. nov. and Massilia lutea sp. nov., isolated from soils in China. Int J Syst Evol Microbiol 56: 459-463. https://doi.org/10.1099/ijs.0.64083-0

Zhang HC, Ma YM, Liu R (2012) Antimicrobial materials derived from the endophytic fungus Fusarium sp. of Eucommia ulmoides. Adv Mater Res 531:346-349. https://doi. org/10.4028/www.scientific.net/AMR.531.346

Zhang H, Tang Y, Ruan C, Bai X (2015) Bioactive secondary metabolites from the endophytic Aspergillus genus. Rec Nat Prod 10:1-16

Zhang H, Xu X, Chen X, Yuan F, Sun B, Xu Y (2017a) Complete genome sequence of the cellulose-producing strain Komagataeibacter nataicola RZS01. Sci Rep 7:4431. https://doi.org/10.1038/s41598-017-04589-6

Zhang Y, Shen H, He X, Thomas BW, Lupwayi NZ, Hao X, Thomas MC, Shi X (2017b) Fertilization shapes bacterial community structure by alteration of soil $\mathrm{pH}$. Front Microbiol 8:1325. https://doi.org/10.3389/fmicb.2017.01325

Zhang Z, Xiong S, Wei Y, Meng X, Wang X, Ma X (2017c) The role of glutamine synthetase isozymes in enhancing nitrogen use efficiency of N-efficient winter wheat. Sci Rep 7:1000. https://doi.org/10.1038/s41598-017-01071-1

Zhao Y, Zhao L, Yang G, Tao J, Bu Y, Liao F (2006) Characterization of a uricase from Bacillus fastidious A.T.C.C. 26904 and its application to serum uric acid assay by a patented kinetic uricase method. Biotechnol Appl Biochem 45:75-80. https://doi.org/10.1042/BA20060028

Zhao L, Xu Y, Sun R, Deng Z, Yang W, Wei G (2011) Identification and characterization of the endophytic plant growth prompter Bacillus cereus strain MQ23 isolated from Sophora alopecuroides root nodules. Braz J Microbiol 42:567-575. https://doi.org/10.1590/S1517-838220110002000022

Zhao LF, Xu YJ, Ma ZQ, Deng ZS, Shan CJ, Wei GH (2013) Colonization and plant growth promoting characterization of endophytic Pseudomonas chlororaphis strain Zong1 isolated from Sophora alopecuroides root nodules. Braz J Microbiol 
44:629-637. https://doi.org/10.1590/S151783822013000200043

Zhao L, Xu Y, Lai X (2017) Antagonistic endophytic bacteria associated with nodules of soybean (Glycine $\max$ L.) and plant growth-promoting properties. Braz J Microbiol. https://doi.org/10.1016/j.bjm.2017.06.007

Zhou JW, Mi JD, Degen AA, Ding LM, Guo XS, Shang ZH, Wang WW, Long RJ (2017) Urinary purine derivatives excretion, rumen microbial nitrogen synthesis and the efficiency of utilization of recycled urea in Tibetan and fine-wool sheep. Anim Feed Sci Technol 227:24-31. https://doi. org/10.1016/j.anifeedsci.2017.03.005

Zilli JE, Baraúna AC, da Silva K, De Meyer SE, Farias ENC, Kaminski PE, da Costa IB, Ardley JK, Willems A, Camacho NN, Dourado Fdos S, O'Hara G (2014) Bradyrhizobium neotropicale sp. nov., isolated from effective nodules of Centrolobium paraense. Int J Syst
Evol Microbiol 64:3950-3957. https://doi.org/10.1099 /ijs.0.065458-0

Zipfel C, Oldroyd GED (2017) Plant signalling in symbiosis and immunity. Nature 543:328-336. https://doi.org/10.1038 /nature22009

Zucchi TD, Kim BY, Kshetrimayum JD, Weon HY, Kwon SW, Goodfellow M (2012) Streptomyces brevispora sp. nov. and Streptomyces laculatispora sp. nov., actinomycetes isolated from soil. Int J Syst Evol Microbiol 62:478-483. https://doi. org/10.1099/ijs.0.029991-0

Zuleta L, Cunha C, de Carvalho F, Ciapina L, Souza R, Mercante F, de Faria S, Baldani J, Straliotto R, Hungria M, de Vasconcelos A (2014) The complete genome of Burkholderia phenoliruptrix strain BR3459a, a symbiont of Mimosa flocculosa: highlighting the coexistence of symbiotic and pathogenic genes. BMC Genomics 15:535. https://doi. org/10.1186/1471-2164-15-535 